Portland State University

PDXScholar

Summer 8-7-2013

\title{
A Dissatisfied Partner: A Conflict - Integration Analysis of Britain's Membership in the European Union
}

Osman Goktug Tanrikulu

Portland State University

Follow this and additional works at: https://pdxscholar.library.pdx.edu/open_access_etds

Part of the Economic Policy Commons, International Relations Commons, and the Other Political Science Commons

Let us know how access to this document benefits you.

\section{Recommended Citation}

Tanrikulu, Osman Goktug, "A Dissatisfied Partner: A Conflict - Integration Analysis of Britain's Membership in the European Union" (2013). Dissertations and Theses. Paper 1064.

https://doi.org/10.15760/etd.1064

This Thesis is brought to you for free and open access. It has been accepted for inclusion in Dissertations and Theses by an authorized administrator of PDXScholar. Please contact us if we can make this document more accessible: pdxscholar@pdx.edu. 


\title{
A Dissatisfied Partner:
}

A Conflict - Integration Analysis of Britain's Membership in the European Union

by

Osman Goktug Tanrikulu

A thesis submitted in partial fulfillment of the requirements for the degree of

\author{
Master of Science \\ in \\ Political Science
}

Thesis Committee:

Birol A. Yesilada, Chair

Ronald L. Tammen

Joseph Lampert

Portland State University

2013 
(C) 2013 Osman Goktug Tanrikulu 


\begin{abstract}
Since 2009, the European Union has faced the worst economic crisis of its history. Due to the devastating impact of the Eurozone crisis on their economies, European countries realized the need to deepen the integration. Without a fiscal union, the Monetary Union would always be prone to economic crises. However, the efforts to reinforce the Union's economy have been hampered by the UK due to its obsession with national sovereignty and lack of European ideals. In opposing further integration, the UK officials have started to speak out about the probability of leaving the EU.

The purpose of this paper is to present benefits and challenges of Britain's EU membership and to assess the consequences of leaving the Union both for the UK and for the EU. This study utilizes Power Transition theory to analyze British impact on European integration. With the perspective of this theory, the UK is defined as a dissatisfied partner. By applying the conflict-cooperation model of Brian Efird, Jacek Kugler and Gaspare Genna, the effect of the UK's dissatisfaction is empirically portrayed.

The empirical findings of the conflict- integration model clearly show that Britain's dissatisfaction has a negative impact on European integration and jeopardizes the future of the Union. Power Transitions analysis indicates that the UK would become an insignificant actor in the international system and lose the opportunity for the Union's leadership if it leaves the EU. On the other hand, although Britain's departure would be a significant loss in terms of capability, economic coherence is more important for the EU. Without enough commitment for
\end{abstract}


the Union, increasing the level of integration with the UK would raise the probability of conflict with the integration process in the future. 


\section{Dedication}

To

My beloved parents.

I am grateful for your unconditional love and support.

Sevgili babacığım ve canım anneciğim Allah sizlerden razı olsun. 


\section{Acknowledgements}

I would like to express my deepest appreciation to my committee chair, Dr. Birol Yeşilada who has not only been my advisor, but also my mentor and coach during my difficult path in the US. I am grateful to him for guiding me through this research and for teaching me how to think as a scholar.

I would like to thank my committee members, Dr. Ronald Tammen and Dr. Joseph Lampert, for sharing their valuable insight with me. Without their critique and efforts this study would not come to this level.

I also would like to give special thanks to Dr. David Kinsella and Dr. Lindsay Benstead. Without the skills and knowledge that I gained from their classes, I would not be able to write this paper. Furthermore, I thank Dr. Veysel Bozkurt from İstanbul University for sharing his vision and encouragement to complete this work.

Moreover, I would like to give special acknowledgement to Liz Blanton Bowles, Susan Neu and Pınar Gürdal from Virginia Tech, and Barbara Pijan. I owe my academic writing skills to these people; without their teachings I would not have been able to develop as a writer.

In addition, I would like to acknowledge the special people who supported and motivated me during my journey: Asena Lawrence, I am grateful for her inspiration, constant support and patience; İlknur Tekin, for sharing her view and experience with me; my boss Chris Anderson and my colleagues at the Office of International Admissions, for their support and toleration; Dr. Serap Emil, for all her encouragement; Marcus Mantik, Murat Saylık and Gary Wood, for their precious friendship; Thomas Pierce, for his fellowship; Fahrettin Ali Fisunoğlu of Claremont Graduate University, for sharing his 
research; Dr. Eylem Özdemir of İstanbul University, for participating in my thesis defense; Karen Popp and Ania Gindlesperger, for helping me get my scholarship and assistantship.

Finally, I am most thankful to my dad, Kenan Tanrıkulu, my mom, Hülya Tanrıkulu, and my brother Alptuğ Tanrıkulu, for their unlimited love and courage to carry on. I always felt their prayers. I also would like to acknowledge my uncle Muammer Ünal for remembering me during my hardship. Whenever I was in distress, all I needed was to think of home. 


\section{Table of Contents}

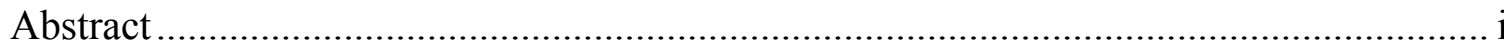

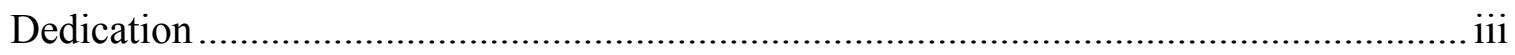

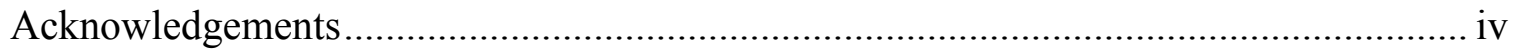

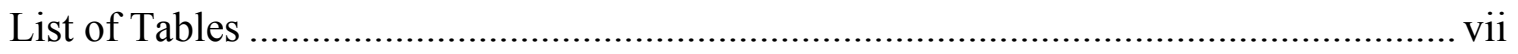

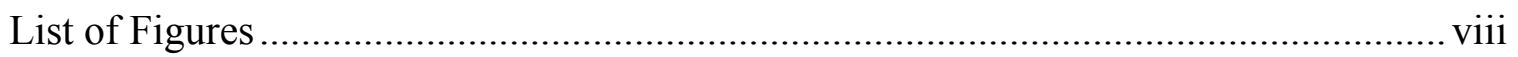

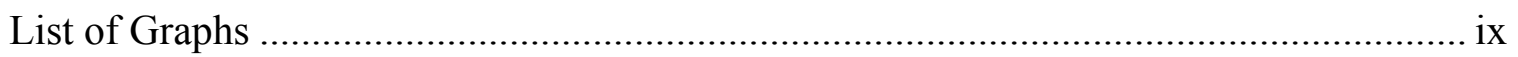

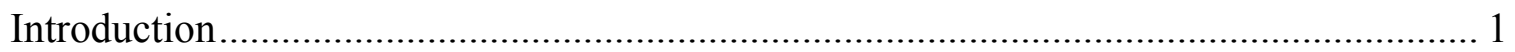

Dissatisfied Partner ............................................................................................. 3

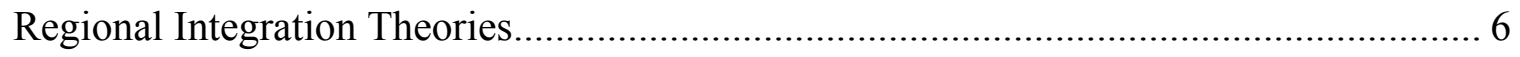

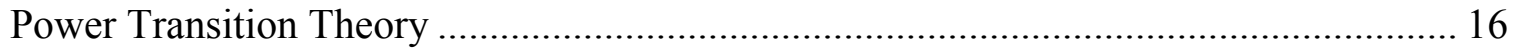

A Historical Preview of the Britain- European Community Relationships ..................... 23

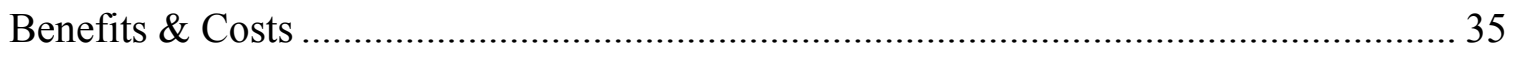

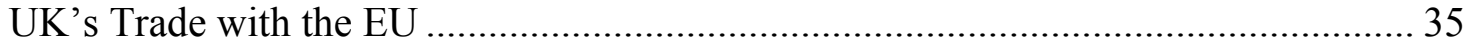

Foreign Direct Investment Received by the UK ................................................. 46

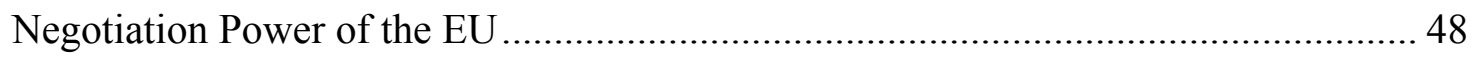

Non-trade Costs and Benefits of EU Membership ................................................... 49

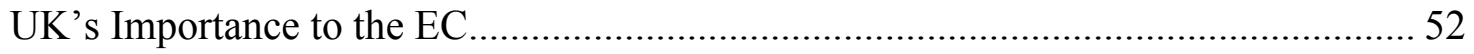

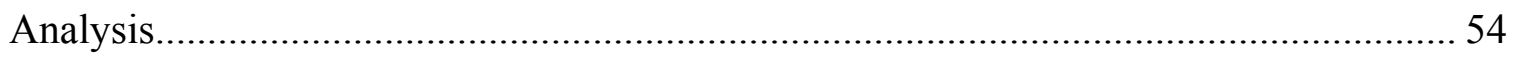

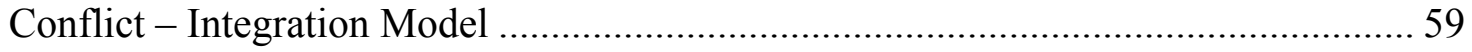

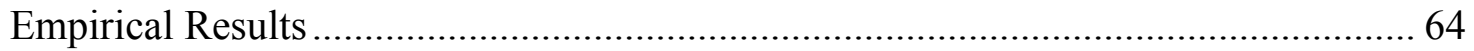

EU's Future Development in the Long Run .................................................... 70

Contribution to the Literature \& Further Research ................................................. 74

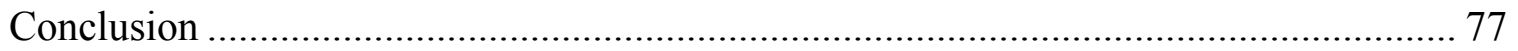

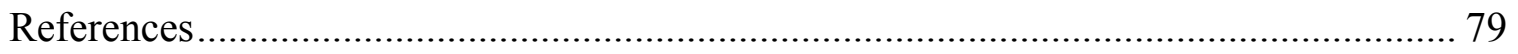




\section{List of Tables}

Table I: The Rotterdam-Antwerp Effect \& The Netherlands Distortion .......................... 38

Table II: The UK Current Account: real versus officially recorded in 2011 ....................38 
List of Figures

Figure I: Global and regional hierarchies …………....................................................2

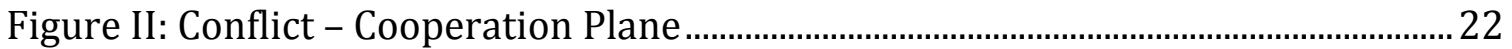

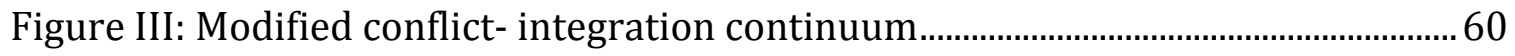

Figure IV: Conflict - integration continuum.........................................................................61 
List of Graphs

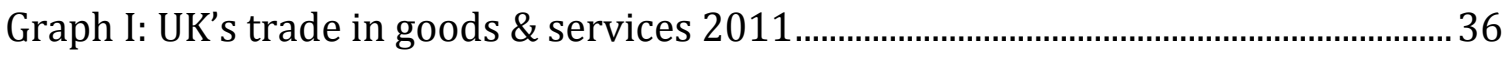

Graph II: Share of the merchandise exports to the EU in total exports (\%) - $2012 \ldots 40$

Graph III: EU's average MFN tariff rates in all products (\%) ..........................................41

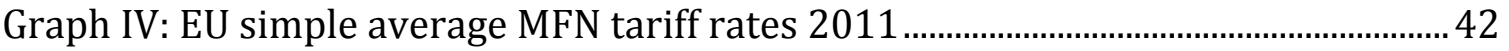

Graph V: UK's trade balance in goods and services 1970-2011 (bn £) ........................... 43

Graph VI: 2011 International transactions in financial services: balance (bn €) ....... 44

Graph VII: UK's services exports by destination 2011 (bn $£$ )............................................. 45

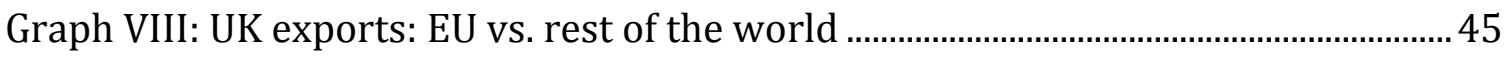

Graph IX: Foreign direct investment, net inflows (\% of GDP) ........................................47

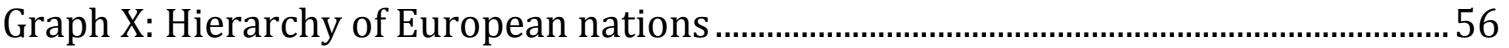

Graph XI: The percentage of citizens who 'tend to trust' the European Commission57

Graph XII: The percentage of people who thinks their country's EU membership is 'a

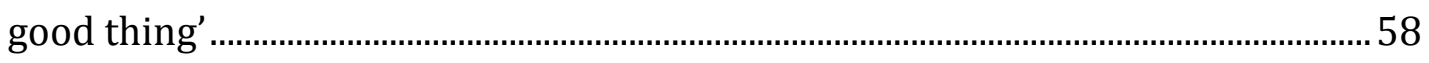

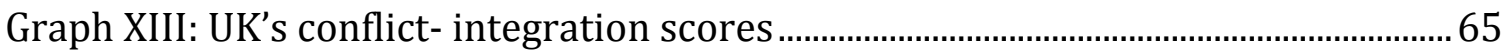

Graph XIV: Forecasting the probability of conflict between the UK and the EU ..............68

Graph XV: Forecasting the probability of conflict between the UK and the EU................ 70

Graph XVI: Forecasting UK's departure from the EU, 1960 - 2100 ................................ 72

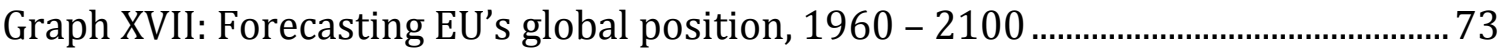




\section{Introduction}

Britain has always been a dissatisfied partner in the Union, but it has never been as close as it is now to relinquishing its membership. Due to the devastating Euro Crisis, the European member states came to a state where further integration is the only suitable option to prevent any future crisis and save the European Union. For this reason, there have been concrete steps towards a fiscal union. However, for a country which has not even become a member of the Monetary Union, due to issues of national sovereignty and lack of European ideals, joining the fiscal union would be almost impossible. As a result, Britain's Prime Minister David Cameron announced the referendum option for British citizens, which stated that they will be able to make the decision whether to stay or leave the European Union.

Annoyed with Britain's constant oppositions and reluctance since joining the Community, other EU member states want Britain to make a decision, and refrain from using depart from the EU as a bargaining tool. However, no one knows exactly what the benefits and challenges would be for Britain and the EU if Britain leaves the EU, or if it stays.

This paper analyzes the benefits and challenges of UK's EU membership as well as consequences of British withdrawal from the Union. By using the conflict- integration model with Power Transitions perspective, this paper assesses the impact of Britain's dissatisfaction on European integration. For this purpose, this study is first going to explain why Britain is a dissatisfied partner. Afterwards, the theoretical perspective of the study is going to be put forth. Then, to be able to understand the current attitude of Britain, a historical preview of the Britain-EU relationships will be presented. Later in the 
study, the benefits and costs of EU membership for both the UK and for the EU will be depicted. In the analysis section, the adaptation of the conflict- integration formula will be explained, and the empirical results will be discussed. 


\section{Dissatisfied Partner}

After winning the Second World War, Britain did not feel the need to integrate itself with countries it had defeated or were occupied due to the hostilities of the war. Though Britain has advanced quickly with the modern world, its citizens desire to preserve the past greatness and traditions of their country. "As one former Conservative MP, Sir Anthony Meyer, put it: 'For France, Europe offers a chance to extend its influence; for Britain, Europe is a damage-limitation exercise"” (Watts \& Pilkington, 2005 , p. 270). Due to its declining fortunes since 1945, Britain has not been able to maintain the global position it once had. Many people admit that Britain's influence on the outcome of international events has significantly declined. However, people are still unconvinced as to why Britain should embrace its continental partners (Watts \& Pilkington, 2005).

Strong attachment to national identity and national sovereignty influence the attitudes of British citizens and leaders towards the EU. There is a tendency among British citizens to see their norms, values, and national history as special and different from other European nations. The vast majority of British leaders and lay people prefer an intergovernmental EU, and are reluctant to create a federal Europe (Menéndez Alarcón, 2004). Simon Bulmer (1992) points out numerous historical reasons why sovereignty has had a strong importance for British policy:

[T] he continuity of institutions since the English Civil War; former world-power status; the successful avoidance, as an island, of full-scale invasion; the position of having 'stood alone' in 1940 together with the prestige gained as a victor; the myth of parliamentary sovereignty; pride in national identity as an aversion to 'homogenization' by European social integration (arguably a variant of public concerns about immigration); and perhaps even popular loyalty to the Crown ( $\mathrm{p}$. 8). 
Britain has never perceived the integration as a political process playing the great ideals of European Union like the other large European Community member states. Aside from Denmark, every member country had political needs that influenced its participation in European integration, which consisted of three European Communities (EC) and the foreign policy co-operation process (European Political Co-operation, EPC). West Germany participated in the European integration to gain international credibility, obtain sovereignty, sustain its new democracy, gain security, and to access to new markets in Europe in the post-war period. For France, European integration was an opportunity to end the repeated French-German hostilities. The integration offered benefits to Italy with similar reasons related to West Germany. For Benelux countries, integration provided security from strong continental neighbors. Integration was an escape for Ireland from the boundaries of Britain. For Greece, Spain and Portugal, European integration was an opportunity to be accepted to the West European family, and to support their democracies. However, the importance of European integration for Britain was due to pragmatism instead of principle (Bulmer, 1992).

Even though there was never a popular excitement about Britain joining the European Community, changes in the international scene and the need to have access to the large European market pushed Britain for accession. It was found advantageous for Britain to apply to the EEC in 1961, only after it became obvious that Britain's international influence had become limited. Some British politicians started to believe that Europe might serve Britain as a ground to increase its influence on events and opinions in the world. Because neither the Commonwealth, nor its connection with the 
US was beneficial for Britain as it once had been, anymore. As Dean Acheson, a former American Secretary of State worded in 1963: "Britain has lost an empire, but not yet found a role" (Watts \& Pilkington, 2005, p. 272). As a result, due to its obsession with national sovereignty, Britain took the gatekeeper role in the $\mathrm{EC}$ to maintain control over national positions and policies (Bulmer, 1992). 


\section{Regional Integration Theories}

Significant amount of international integration theories have been developed to understand the European Union phenomenon. However, due to its complexity, none of these integration theories have been able to explain altogether how European Union advanced and what it is going to become. So far, theories of regional integration have been more successful in explaining the development of the Union than where it will end up. This paper neither aims to contribute to the theoretical explanations of the EU integration, nor attempts to predict the final state of the Union. But to give an overview of the regional integration theories to understand the integration phenomenon and the reasons why countries go into integration.

Integration is a concept that has different connotations in social sciences. Some scholars define integration as a political phenomenon and some others as an economic phenomenon. For instance, Karl Deutsch perceives a community aspect from integration

as

the attainment, within a territory, of a "sense of community" and of institutions and practices strong enough and widespread enough to assure, for a "long" time, dependable expectations of "peaceful change" among its population. By sense of community we mean a belief ... that common social problems must and can be resolved by processes of "peaceful change" (Deutsch, 1969, p. 5).

Differing from Karl Deutsch, Ernst Haas sees a political occurrence by defining integration as

the process whereby political actors in several distinct national settings are persuaded to shift their loyalties, expectations and political activities toward a new center, whose institutions possess or demand jurisdiction over pre-existing national states (Haas, 1968, p. 16). 
There are several core integration theories that attempt to explain the European integration process: neofunctionalism, intergovernmentalism, liberal intergovernmentalism and confederalism.

Neofunctionalism is a theory which focuses on the supranational institutions of the EU. Even though neofunctionalism intended to formulate a general international relations theory, which can explain regional integration processes, political and economic integration of Europe became the core interest. Neofunctionalists ask how economic integration leads to political integration; and at the end of this integration, what kind of political unity will take place. Unlike realists, neofunctionalists do not see international relations as a zero-sum game. When states are involved, economic integration will strengthen all. Thus, political integration will come after (Strøby-Jensen, 2010). By emphasizing the political agency in the integration process instead of technocratic automaticity, neofunctionalism differs from David Mitrany's functionalism. The integration process is mainly backed by the determined actors who are driven by their self-interests. Concentrating on the actors and their interactions, neofunctionalism emphasizes a process in integration itself instead of outcomes. Additionally, the actors seek their interests in a pluralist political environment (Rosamond, 2000).

According to Rosamond (2000), neofunctionalism has features of pluralist theory in political science. Pluralist theory sees society as a combination of various interests of many different groups. Diverse interests of different groups in the political structure compete with each other to influence the governance for the outcomes of policies. Furthermore, according to pluralism, elites are not the only influencers in society. Consequently, the basis of politics is composed of group activity. 
According to the neofunctionalist logic, integration starts when two or more countries agree to work together in an economic sector - let us say sector A. In order to increase their efficiency, countries agree to establish a supranational structure to manage common working. However, even though countries get some utility from their integration in sector A, getting higher levels of benefits pushes countries to spread integration to the connected sectors of $\mathrm{A}$, such as sectors $\mathrm{B}$ and $\mathrm{C}$. As a result, the integration in one sector creates a functional force to extend integration to related sectors (Rosamond, 2000).

Once established, supranational institutions start to influence the integration process. Supranational structure, which is the high authority, encourages the deepening of integration between countries by increasing the number of sectors covered, and promotes institutionalization at the regional level (Rosamond, 2000). Additionally, having their own political agendas, supranational institutions suppress the interests of the member states. For instance, in the European Parliament, representatives of the countries are aligned according to party politics and ideology instead of national interests (StrøbyJensen, 2010).

Explaining the integration process, spillover is one of the most important concepts of neofunctionalism. According to Ernst Haas (1968), spillover is the pressure for further integration within an economic sector or in related sectors when integration once generated in. Differing from Haas, Lindberg ascribes spillover a complementary character. Spillover is the additional successive actions that have to be taken in order to assure the initial goal (Lindberg, 1963). For instance, the core purpose might be free movement of workers across EU borders. However, in order achieve that goal, countries realize that different employment rules between them should be regularized first. 
Consequently, in order to establish free movement of labor between the member countries, which is the main goal, additional political goals might be formulated to prevail over the barriers (Strøby-Jensen, 2010). As a result, the logic of spillover relies on expansion and deepening that more economic functions are pulled into the integration process (Rosamond, 2000). Therefore, this perspective of the spillover is also called 'functional spillover'. For example, establishing a customs union among some countries might create the need for stable exchange rate parities. Therefore, establishing a customs union can also bring exchange rate coordination between member states. Overall, functional spillover is helpful to understand the transition from the ECSC to the Economic and Monetary Union.

Loyalty transference, which can also be referred as elite socialization, is another important component of neofunctionalist reasoning of integration. The elite socialization argument of neofunctionalism claims that people who are involved in the supranational level policy making process develop a tendency towards European loyalties and inclinations. For example, members of the European Commission are expected to have a European perspective rather than having national priorities (Rosamond, 2000). According to Haas (1968), political integration consists of the transfer of loyalties, prospects, and political actions of political actors to a new authority which has jurisdictional power over the members of the previous nation states. Explaining the transition to a new form of community, neofunctionalists put emphasis on elite loyalties instead of the mass public. By using the loyalty aspect, neofunctionalists seek to explain the situations where technocratic automaticity between governments is hindered by ideological elements. For example, French president Charles de Gaulle's nationalistic approach towards the EC 
system created hard times for neofunctionalists (Yeşilada \& Wood, 2010). According to the neofunctionalists, elite groups will develop loyalties towards the supranational institutions with pan-European norms as European integration proceeds. In this way, negotiations are going to be more technocratic rather than being politicized.

Consequently, coming to an agreement is easier by shifting towards more technical problems in the integration agenda (Strøby-Jensen, 2010).

Besides the civil officials, the organized interest groups promote supranationalism. According to neofunctionalist theory, as economic and political integration develops in a region, interest groups will keep up with the development of the supranational institutions. For instance, after the European Community was established, national industrial and employers' organizations established BUSINESSEUROPE, a common European organization in 1958 (Rosamond, 2000). As actors involve in the integration process, they generate political pressure for deeper integration. Because of the economic and political integration, interest groups develop their own supranational interest. Therefore, interest groups will force governments to speed up the integration process (Strøby-Jensen, 2010). Additionally, when there is anticipation about integration in significant economic sectors, elites are expected to approve the idea for further integration (Rosamond, 2000). According to Haas (1971), neofunctionalism has two major flaws. First, by analyzing the decision-making mechanisms and societal features in pluralistic societies, it is dubious to apply the neofunctionalism to the integration models other than European integration. Second, by having a vague understanding of the integration conditions, neofunctionalism has a dependent variable problem (Haas, 1971). 
After neofunctionalism, intergovernmentalism has become the core theory that integration scholarship has applied to analyze EU. Intergovernmentalism is a state-centric conceptual explanation of European Integration. While attributing to the interests and actions of the nation-states in European integration, intergovernmentalism argues that integration can only cover the areas which will not diminish state sovereignty. The foundations of intergovernmentalism rely on the realist theory of international relations (Cini, 2010). Realism assumes that states are the primary actors in the international arena. Additionally, state behavior is the rational pursuit of self-interest (Morgenthau, 2006). As stated by intergovernmentalism, integration is basically in the control of the states. Therefore, intergovernmentalists are challenged by the question of why states should create an establishment and transfer some of their policy sovereignty to it. As state-centrism claims, EU integration is the result of the interest interaction between states that is negotiated by EU institutions. For instance, the Council of Ministers is a forum where national interests are interchanged and come to an understanding; there is an intergovernmental mechanism in the EU system. Accordingly, state-centrists emphasize intergovernmental bargains while defining integration (Rosamond, 2000).

Intergovernmentalism defines the European Union as cooperation instead of integration. According to the intergovernmentalists, the behavior of the European countries is simply a more institutionalized form of cooperation that seeks to overcome policy issues. There is no ideology or idealism behind the aims of the European countries; therefore, intergovernmentalists refuse that European Union is going to become a political union (Cini, 2010). 
Intergovernmentalism does not reject that some functions are transferred from the member states to the European institutions. For a more effective cooperation, in the pursuit of their self-interest, countries pass some functions to the institutions. However, intergovernmentalism does not attribute supranational features, such as independence and autonomy to the European institutions. Therefore, the function of the European institutions in contentious policy areas is limited (Cini, 2010).

The foundations of intergovernmentalism were built by Stanley Hoffman. Hoffman criticized neofunctionalism because it was missing the setting within which integration was processing. He highlighted that international politics continued to have permanent conflicts about state interests. Additionally, cultural differences which influence state interests are ignored by neofunctionalism (Hoffman, 1966).

According to Hoffman (1966), even though national sovereignty is domesticated, the nation state is not taken over. Hoffman points out how resilient national states are in the international arena by arguing that nation states are obstinate, not obsolete. State governments have still been powerful because they have internal sovereignty in their territories, and in being democratically elected, they gain political legitimacy (Hoffman, 1966).

Hoffman (1966) made a distinction between low politics and high politics in integration. Integration at the level of high politics, issues related to national sovereignty and national identity confronts more restraints than the integration at low political level, which contains economic issues. Functional spillover might work at low politics, but it cannot be assured that states are going to let integration occur at high politics (Hoffman, 1966). 
Another well-known regional integration theory is liberal intergovernmentalism. According to liberal intergovernmentalism, the European Union governs economic interdependence between member states by a coordinated policy bargain. The theory highlights the power and the preferences of states. Liberal intergovernmentalism is based on the rational actor model. States are assumed as rational actors, and they make use of their evaluated preferences while achieving goals. Even though the representatives of the member states have the responsibility to display domestic priorities, the decisions at the EU level are taken by negotiation (Cini, 2010).

Liberal intergovernmentalism has two aspects for explaining the European integration: demand for cooperation and supply of integration. In order to understand the European integration, both the demand for cooperation, which is emerged from the national polity, and the supply of integration, appearing from the inter-state negotiations, have to be analyzed (Strøby-Jensen, 2010). Andrew Moravcsik (1992) argues that societal factors give rise to integration because domestic interests shape state preferences, which in turn affect state relations.

Moravcsik (1992) theorizes European integration as a two-level game by liberal intergovernmentalism. Two-level game is the metaphor used to describe the connection between domestic politics and international politics. Moravcsik's two-level game is composed of a liberal thesis of national preference formation and an intergovernmentalist approach of bargaining between states. Liberal theory of national preferences, which is the demand side of the integration, claims that national preferences of the member states are shaped according to the circumstances of their domestic politics. However, classic intergovernmentalism implies that national interests are determined according to where a 
state sees itself in the international system relatively. As claimed by Moravcsik, competing political powers in the society determine national interests. Thus, what states represent in the international arena are the interests of dominant groups within societies. Therefore, in order to understand how states interact with each other, it is essential to comprehend their domestic politics (Moravcsik, 1992).

Besides liberal intergovernmentalism, confederalism depicts the EU as a statecentric account. Confederalism is a certain type of intergovernmentalism in which states preserve their sovereignty under an institutional body. According to confederalism, Community is an example of the highest level of common subject matter in European integration. This common matter is building larger markets to support joint interests of member states, which join voluntarily. Confederalism is pursued by states for their economic interests in the international system. Creating institutions is crucial for the life and stability of the system (Rosamond, 2000).

In spite of their explanatory capacity, none of these theories help us analyze the benefits and challenges of the UK's EU membership as well as consequences of British withdrawal from the Union, which is the research question of this paper. There are two primary problems with these regional integration theories. First, aforementioned theories attempt to explain integration process, however, they do not tell us anything about the possible outcomes of the perspectives or the attitudes of the member states. Therefore, by using these regional integration theories it is difficult to understand or estimate the consequences of Britain's attitude towards the European integration. Second, these theories do not take into account the individual influence level of the member states to integration process. These regional integration theories assume that each member state of 
a regional integration has the same capacity to influence the integration process. For instance, both being the members of the EU, Malta and Britain does not have the same capacity to influence the European integration process. For these reasons, this paper will employ Power Transition theory as the theoretical perspective to analyze its research question. 
Power Transition Theory

The analysis in this study is based on Power Transition theory, which was started with A. F. K. Organski's (1968) pioneering work. Power Transitions is a rationalist theory which describes a hierarchical system. According to this theory, the distribution of power in the international system is uneven. There is a dominant nation at the top of the system that controls the largest proportion of resources in the system. However, the dominant nation is not a hegemon. The dominant nation maintains its position by dominating the potential rivals and by governing the international system in a way that satisfies its allies. Below the dominant power, there are great powers in the power pyramid, and below those there are middle powers and small powers respectively (Organski, 1968). Power Transitions perspective tells us that currently, the United States is the dominant power in the international power hierarchy. According to the same perspective, at present, the great powers are China, Japan, Germany or the European Union, and Russia. Power transition theory explains that great powers help maintain the international system and allocates the resources. Among the great powers, a challenger to the dominant power might rise. France, Brazil and Italy are middle powers. These nations have significant power but are insufficient in challenging the dominant power for international control (Tammen et al., 2000).

According to Power Transition theory, power defines the conditions of war and peace in the international system. Power is defined as the ability to make opponents comply with demands. Power is composed of three elements: population, economic productivity (GDP) and the ability of the political system in extracting resources from society. Population is an essential component of the power equation; however, in order to 
be relatively powerful, population must be more productive than the rivals. High political capacity is the other requirement to be powerful or developed. Politically capable governments can relatively extract more resources and utilize them for national goals (Organski \& Kugler, 1980).

The theory claims that war and peace decisions are made according to satisfaction with the international rules or hierarchy. Dissatisfied nations will most likely challenge the status quo; however, if these nations are not in power parity with the global or regional dominant power, war will be less likely. At the great power level, conflict does not occur frequently because most of these nations are satisfied with the rules of the international system. Great powers of the hierarchy are most likely to be satisfied with the international system because they are involved in the process of setting the rules with the dominant power. The few nations at the top and many at the bottom are dissatisfied with the international system because they are benefiting from the system less than their expectations. These dissatisfied nations consider the international system as hostile and dominated by the few. Their dissatisfaction might be related to historical reasons, such as Germany prior to World Wars I and II, or by ideological reasons, like the Soviet Union. For example, currently, China is considered as a dissatisfied country because of not being fully integrated into the dominant nation's regime. However, China's dissatisfaction in the future depends on its integration into international institutions and adoption of international law. In being dissatisfied with the global status quo, dissatisfied nations want to change the rules and norms of the international system. According to power transition theory, jointly satisfied nations are most likely to cooperate. The security alliance in NATO and economic integration in the European Union are examples. If the 
challenger is dissatisfied, the probability of war with the satisfied nations increases. A Cold War is highly probable when the dissatisfied nation is not powerful enough to challenge the dominant power. If nations are dissatisfied with the international system because of same reasons, they might build an alliance against the status quo (Organski, 1968; Tammen et al., 2000). Consequently, Power Transition theory accounts both for conflict and cooperation.

Power Transition defines the probability of war by formulizing the conditions of parity and overtaking. The condition of parity occurs in the international hierarchy when a challenger develops more than 80 percent of the resources of the dominant power. When the challenger exceeds 20 percent of the resources of the dominant power, the parity ends. The other concept that Power Transition theory introduces is the overtaking. Overtaking happens when a challenger enters the steep growth section of the growth track and catches a higher economic growth rate than the dominant nation. In order to overtake the dominant nation, the challenger has to enter into parity with the dominant nation by either increased productivity or by political capacity in relative terms. Parity and overtaking increases the probability of conflict (Tammen et al., 2000). However, parity and overtaking are not the direct cause of conflict. The conflict is highly related to the dissatisfaction of the challenger with the status quo. The higher the determination of the overtaking challenger, which is in parity, to change the international rules, the higher the probability of conflict. The defender can prevent the conflict with the challenger by incorporating its interests into the international system. In other words, by increasing the satisfaction level of the challenger with the status quo, the probability of conflict can be decreased. Conflict in World War I and II was the result of Germany's overtaking the 
United Kingdom just prior to World War I and II. Likewise, Iran - Iraq conflict occurred right after Iraq overtook Iran (Organski, 1968; Tammen et al., 2000; Kugler, Tammen, \& Efird, 2004).

Power Transition theory informs us about the timing of the wars. Wars between great powers occur when their relative power is in parity. When there is a clearly superior dominant power in the hierarchy, an attempt to challenge the dominant power will be less likely. Therefore, disproportionate power will generate peace. When there is equality in relative powers, the potential of conflict increases (Tammen et al., 2000; Lemke, 2002). According to Douglas Lemke (2002), there are sub-systems within the overall international power hierarchy. These sub-systems function similar to each other and to the global power hierarchy. Lemke (2002) explains this series of parallel power hierarchies in his multiple-hierarchy model, which is the theoretical revision of Power Transition theory. The multiple-hierarchy model asserts that within the global power pyramid there are smaller power pyramids that represent local/ regional systems or subhierarchies. As it can be seen in Figure I, the big block composed of USA, EU and China represents the global hierarchy. The size of each block illustrates the power of the nation. Inside the global hierarchy we see the regional hierarchies. Similar to the overall international power hierarchy, each local/ regional hierarchy has a dominant power which leads the local affairs and tries to preserve the status quo in the region. As the dominant power in the global international system, the regional dominant power anticipates gains from maintaining or building the status quo. As it is portrayed in Figure I, some nations are dissatisfied with the global or regional hierarchy. Consequently, the multiple- 
hierarchy model argues that there are local hierarchies in South America, the Middle East, the Far East and Africa (Lemke, 2002; Tammen et al., 2000).

Figure I: Global and regional hierarchies

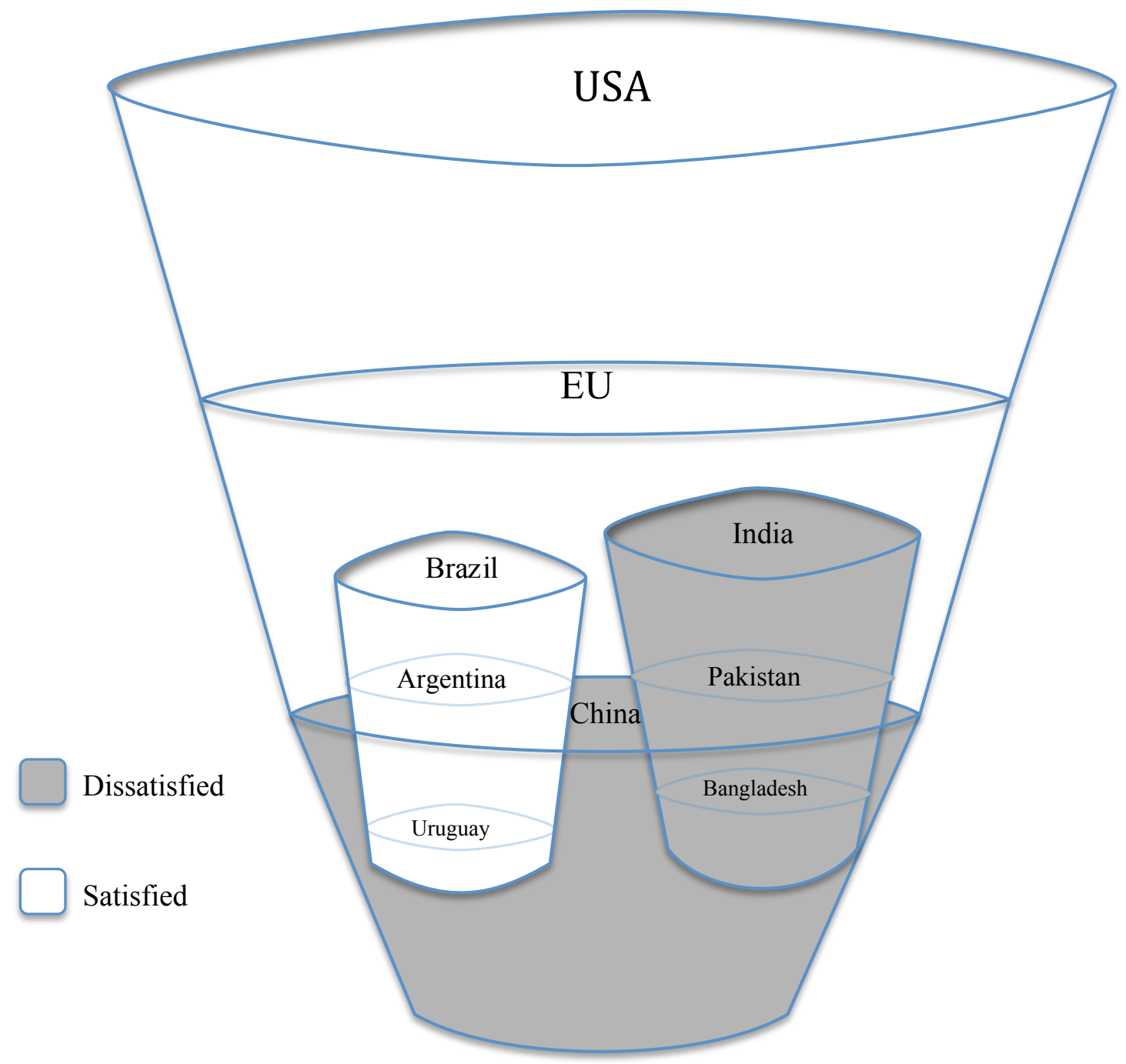

Source: Consequences of Reversing the EU Integration (Kugler, Yeşilada, \& Fisunoğlu, in press)

The expectations of the multiple-hierarchy model about peace and war in regional systems are similar to the global hierarchy system. When the regional dominant power is preponderant in the regional hierarchy, the probability of peace in the region is high. However, when a local dissatisfied state rises to parity with the dominant state in the local hierarchy, the probability of war increases in the regional system (Lemke, 2002). 
For example, when it is evaluated in terms the multiple hierarchy model, the South American regional hierarchy is more stable than the Middle Eastern regional hierarchy. Because in the South American regional hierarchy there is preponderance between the local dominant power, Brazil and the great power, Argentina in terms of both GDP and population. On the other hand, in the Middle Eastern regional hierarchy the dominant power, Turkey and the great power, Iran are in parity. As in the global hierarchy, the probability of war increases in the regional hierarchy when a dissatisfied local challenger achieves parity with the local dominant power (Yeşilada, Efird, \& Noordijk, 2006).

Lemke (2002) argues that regional hierarchies are not independent from the interference of the dominant and great powers of the global system. When a dispute in a local hierarchy affects the interests of the dominant power or a great power, there might be interference from the global actors to a local hierarchy. Overt military intervention is the most apparent interference of the great powers to local power hierarchies. However, indirect interference is also possible, such as supporting one or another member of the local hierarchy by providing economic or military resources, or by sharing intelligence. Nevertheless, without the strong interest of the global great powers, the regional hierarchies are expected to function in a way similar to the global power hierarchy. In the absence of great power intervention, dissatisfaction with the local status quo and parity between the local dominant power and a local challenger are expected to increase the probability of war in that local hierarchy (Lemke, 2002).

When we look at the European Union from Power Transitions perspective, we see countries on the cooperation side of the conflict-cooperation scale (Figure II). When we look closer, it becomes visible that even though EU member countries are cooperating, 
the level of satisfaction differs between the members. Being more satisfied with the status quo, some member countries are closer to the integration tip, which is the highest level of cooperation, of the conflict-cooperation scale. These countries are the members of the monetary union, and they are willing to deepen the integration with the banking union after the Euro crisis. Countries like Britain, Sweden and Denmark are not as close to the integration end of the conflict-cooperation scale as the Euro countries since they did not give up their national currencies.

Figure II: Conflict - Cooperation Plane

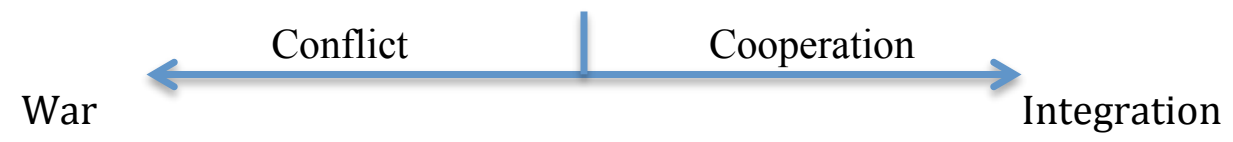

Compared to other EU countries the UK is a dissatisfied member in the integration. According to Power Transitions, the dissatisfaction of the UK is significant because being one of the powerful nations in the EU, Britain has the capacity to influence the integration process. The higher the level of productivity and population of a country, the more capacity it has to shape outcomes in a global or a regional status quo. Consequently, due to its relative capability, the dissatisfaction of the UK is threatening the integration process of the EU. 


\section{A Historical Preview of the Britain- European Community Relationships}

To be able to understand the dissatisfaction of Britain in the European Union today, it is significant to review the vision of the country after the Second World War and how the leaders of Britain perceived European integration since the establishment of the European Community. According to Watts and Pilkington (2005), the British approach to European policies since the Second World War has had two primary aspects:

- an emphasis upon the importance of Britain's transatlantic ties as a central tenet of foreign policy;

- a preference for intergovernmentalism over integrationalism - a belief in the central role of national governments that renders any federalist notions as out of the question for British ministers (p. 279).

Winston Churchill suggested a union to be established in Europe, however he never envisioned Britain to be part of it. In a speech in 1946 in Zurich, Switzerland, Winston Churchill emphasized the union of Europe by bringing Germany and France together to prevent a third and atomic world war. Although Churchill's Zurich speech gave the impression that Britain was leading the growing European movement, his true vision for Britain was laid in 1930:

We see nothing but good and hope in a richer, freer, more contented European commonality. But we have our own dreams and our own task. We are with Europe but not of it (Watts \& Pilkington, 2005, pp. 8-9).

Churchill had a federalist view for Europe; however, his federalism did not see Britain in that federation. According to Churchill, Britain had a unique position at the intersection of an Atlantic Alliance, linking North America to Europe, and Europe itself and the British Commonwealth. Churchill shared the smugness of the British people who believed in the greatness of Britain which won the war (Watts \& Pilkington, 2005). As stated by this view, "Britain was a global power, and only incidentally a European power" 
(George, 1998, p. 39). The policies of the major Departments of State, the Treasury and the Foreign Office were formulated according to this globalist view. The British people could understand why uniting would help the devastated continental European countries; however, they did not see Britain as a member of the band. As a result of that view, being one of the three world powers besides the USA and Soviet Union, Britain did not need Europe (George, 1998; Watts \& Pilkington, 2005). This sentiment was expressed by people who had power and influence in Britain that, "Europe had been fatally damaged by the war and that Britain should avoid chaining itself to a corpse" (Watts \& Pilkington, 2005, p. 9).

In 1940s the attitude of Britain towards European integration was mostly rejection and counter-measures, and this attitude can still be observed today. There are three events in 1940s that exemplify typical British response to European unification. First, in 1947 Britain blocked the negotiations that planned to widen the customs union in Europe, which was already established between Belgium, the Netherlands and Luxemburg with the Benelux Agreement. Since a customs union should have a supervisory council, or a supranational assembly, British ministers were concerned that Britain's sovereignty would diminish. Second, after signing the treaty of Brussels in 1948 between Britain, France, and Benelux countries against the Soviet expansionism, signatories wanted to further the defense agreement and establish the Western European Union (WEU) by creating a unified defense policy and military alliance among non-communist European states. Due to the consideration of economic and political co-operation, the establishment of an assembly or a parliament as a governing body came up as an idea. However, Britain acted against the idea of pooling some degree of authority to govern the WEU. British 
foreign secretary of the post-war Attlee government Ernest Bevin expressed that the community was established for defense purposes only. As a result, instead of an assembly or a parliament, a Consultative Permanent Council was established. Lastly, when the Organization for European Economic Co-operation (OEEC) was established to administer the European Recovery Program (ERP) under the Marshall Aid, due to the economic success of the organization in Europe, European federalists wanted to equip OEEC with an executive decision which made the capability to form a European administrative institution. The European enthusiasts wanted to create an institution which would become the force of European integration. They even chose a candidate, the Belgian Paul-Henri Spaak, for this purpose. However, the Foreign Office of Britain disagreed with establishing a supranational governing structure for the OEEC and vetoed the nomination of Spaak as chairman of the organization. Instead, Britain supported Oliver Franks, who was an anti-federalist from Whitehall (Gowland \& Turner, 2000; Greenwood, 1996; Watts \& Pilkington, 2005).

In seeing Britain as a world power, Europe was not a priority for the Attlee government. The Attlee government declined to participate when the negotiations of the European Coal and Steel Community started in 1950 (George, 1998). According to Duncan Watts and Colin Pilkington (2005), Britain refused to join the negotiations for the Coal and Steel Community in 1950 because both Robert Schuman and Jean Monnet made it clear that besides the economic benefits, the primary purpose was to set the stage for a political union. In June 1950, the Chancellor of the Exchequer, Sir Stafford Cripps, expressed the ministerial attitude towards establishing a European federation starting with the Coal and Steel Community: 
In our view, participation in a political federation, limited to Western Europe, is not compatible either with our Commonwealth ties, our obligations as a member of the wider Atlantic community or as a World Power (Watts \& Pilkington, 2005, p. 16)

Once there was an agreement on the European Economic Community (EEC), the British tried to attract the members of the EEC to join a customs-free trade in industrial goods. All the seventeen members of the OEEC would be able to join this free trade area. Britain's counter-plan was aimed to establish a low-tariff common market but to avoid political or integrationist implications. In 1959, the UK, Portugal, Norway, Sweden, Denmark, Austria and Switzerland established the European Free Trade Area (EFTA), which was a loose free trade association and intergovernmental in character. Unlike the EEC, EFTA was not aimed to unite European peoples. As a result, with the leadership of Britain, a rival body was created against the EEC (Gowland \& Turner, 2000; Watts \& Pilkington, 2005).

EFTA came into force in 1960, but it did not take so long for the British government to seek membership of the EEC. There were four major reasons why the Macmillan government started to contemplate to join the Six (Belgium, France, Italy, Luxembourg, the Netherlands and West Germany) in 1961. First, Britain started to realize after the Suez affair in 1956 that it was not a world power anymore. It was identified that Britain needed to find a new world role, therefore, many people pointed out Europe. Second, even though in the 1950s and 1960s the British economy was booming, the economic development of the EEC members, which had almost doubled their living standards in the same time period, made membership appealing. Third, joining together for the first time since the Napoleonic epoch, Britain did not want to 
confront a Europe without any British input. Watching the development of political and economic institutions that function as barriers for outsiders, Britain did not want to be excluded from shaping the European policy and the European market. Lastly, it became clear that the United States viewed EFTA as creating complications in Europe. If one day the Six were to be developed into a Federal State, the United States of Europe may become more important for the US than the UK. Due to the risk of losing its links with the US, Britain decided to apply for EEC membership (George, 1998; Greenwood, 1996; Watts \& Pilkington, 2005).

In January 1963 President de Gaulle announced the unilateral French veto on British membership. The French President indicated his primary reason as Britain had not accepted a European vocation yet, and expressed his doubts: "England in fact is insular, maritime, bound by her trade, her markets, her supplies, to countries that are very diverse and often very far away... How can England, as she lives, as she produces, as she trades, be incorporated in the Common Market?" (George, 1998, p. 34). On the other hand, Watts and Pilkington points out another reason for de Gaulle's veto. According to De Gaulle, having failed from the outside, Britain applied for membership to ruin the EEC from the inside. When the Britain- EEC talks were stuck due to Britain's protectionism for its trade links with the Commonwealth, De Gaulle interpreted the situation as Britain's attempt to destroy the agricultural policy of the EEC. As a result, De Gaulle exercised his veto to prevent the British joining the EEC (2005).

Even though De Gaulle became the target for critiques after vetoing the first British bid, many believed that Britain's attitude and hesitations played significant roles in the failure of the first application. Throughout the negotiations Britain gave the 
impression that by applying to the Community, they were doing a favor for Europe. Watts and Pilkington quotes a political commentator in their study: "It was in many respects as if Britain had decided that the EEC was worthy of British membership, and not the way around" $(2005$, p. 26). This attitude of Britain has been present in its relationships with Europe ever since, and will be seen clearly between Margaret Thatcher and the EC. Furthermore, Britain was hesitant about the membership due to the terms of entry. Britain demanded more and more compromises for the Commonwealth, EFTA and for British farmers. Even according to one study, before submitting the formal application, British Prime Minister Harold Macmillan knew that De Gaulle was going to hinder the British accession (Watts \& Pilkington, 2005).

Being blocked by de Gaulle for the second time, membership negotiations for Britain started only after the French President resigned from office. After refusing to accept Britain's second application, in 1967 de Gaulle announced that Britain was still not ready to become a member of the European Community (after a merger took place in 1965). Once Georges Pompidou became the new French President in 1969, the French opposition for British membership ended. Pompidou did not have any deep-rooted demur for British membership like his predecessor. Consequently, negotiations went smoothly and Britain signed the Treaty of Accession in Brussels on January $1^{\text {st }} 1972$ (George, 1998).

Even during its third application, there were not any changes on the British perspective towards the European Community. Instead of having any European ideals, both Macmillan and Wilson Administrations pursued membership of the Communities to be able to direct how Europe ought to be linked to the world system. During British 
applications "[t]here was no conversion to the ideal of European union that was espoused by the leaders of the founder states; there was no attempt to sell the idea of British membership in anything other than pragmatic terms to the British electorate; there was no abandonment at either official or popular level of a commitment to a strong sense of national identity, which remained the basis for the electoral appeals of politicians in all parties; there was no abandonment of the attachment of the special relationship with the United States, or of the commitment at both official and popular levels to the Atlantic Alliance as the basis of international stability" (George, 1998, p. 40).

All these subjects would continue to affect Britain's relationship with the EC after 1970. Failing to embrace the ideal of European Union, disagreements continued to arise with the other member states. The approach of the British statesmen and women continued to be influenced by the electorate that disliked the EC. Due to the strong sense of national identity, the British representatives have had difficulty putting the interests of Europe before Britain in the Council of Ministers of the EC, where clashes have occurred. Mostly, EC's relationship with the United States and EC's relationship with the global order have been the issues of conflict with the Community. Therefore, Britain has many times been regarded as either the US Trojan Horse or the awkward partner in the Community (George, 1998).

Margaret Thatcher also followed the view of British superiority to Europe in her governance. Re-negotiating Britain's contribution to the European budget fiercely from 1979 to 1984 , her behavior was strongly disapproved by the other EC members. At one point the French Prime Minister Jacques Chirac even called for Britain's dismissal from the EC. She: 
- despised committees;

- was very reluctant to agree to any compromise or consensus;

- would not, without a real struggle, do any deal which detracted from her demands;

- believed in her own judgment - her position in any argument was that she was right and everyone else was wrong (Watts \& Pilkington, 2005, p. 32).

After five years of insisting on her terms, Thatcher gained more than reasonable. However, the cost was damaged future Britain - Europe relations. "The insistent demands made by Thatcher, and her domineering and insulting treatment [for] her supposed partners, had at times almost turned Britain into a pariah in European circles" (Watts \& Pilkington, 2005, p. 35).

Britain played an obstructive role when the European integration attempted to progress with the EMU. Jacques Delors proposed a three-step pathway for EMU, which coordinated economic policies between the EC countries within the ERM; established an independent European Central Bank (ECB); and to use a single European currency. Margaret Thatcher signed the agreement to join the ERM only because the foreign secretary Geoffrey Howe and the Chancellor of the Exchequer Nigel Lawson from her cabinet threatened to resign if she did not sign the agreement. Besides, she signed the agreement with preconditions: "Internal market arrangements must be completed; All exchange controls should be abolished; There should be a free and open market in financial services; There must be a strengthening of competition policy" (Watts \& Pilkington, 2005, p. 46). Later on, for the other steps of the Delors Plan, the British prime minister voted down three times in intergovernmental conferences. Only after calling a simple majority vote on stage under the presidency of Italian Prime Minister Bettino 
Craxi, European leaders were able to vote against Thatcher. Britain found herself isolated against eleven (George, 1998; Greenwood, 1996; Watts \& Pilkington, 2005).

The legacy of Thatcher even constrained the maneuver of her successor John Major during his premiership. Due to the opposition of the eurosceptics from the Tory bank benches, John Major became as opposed to the European integration as his predecessor. The pamphlet which was published by the Foreign and Commonwealth Office during Britain's EC presidency in 1992 indicates Britain's anti-integrationist vision:

The original Community treaties aimed at an 'ever-closer-union among the peoples of Europe'. The government are committed to closer co-operation with our Community partners. This has brought political and economic benefits. But the Government don't want, and won't have, a United States of Europe (Watts \& Pilkington, 2005, p. 118).

Using the terminology of European federalism and Christian Democracy, British aimed to limit the extent of interventions by the Commission to national affairs. During the Maastricht debates under the British presidency in 1992, the British Prime Minister John Major promoted subsidiarity (George, 1998; Gowland \& Turner, 2000). Subsidiarity meant that:

- proposals by the centre in Brussels should be implemented according to the decisions of national or regional government;

- no major policy decision should be made in Brussels if it is more properly the concern of national or regional government (Watts \& Pilkington, 2005, p. 51).

John Major broke the unwritten rules of the EU by using the veto weapon for party politics. When Chancellor Kohl of Germany and President Mitterrand of France agreed to support Jean-Luc Dehaene, the prime minister of Belgium, as the new president of the Commission in 1994, John Major stated that he might only settle for the Dutch prime 
minister Ruud Lubbers if he could not have the British commissioner as the president. The British stressed that due to the secret deal between Kohl and Mitterrand supporting Jean-Luc Dehaene for the presidency, the British veto would be used to prevent the Belgian. Britain's reaction was interpreted as Major's attempt to give an impression to the eurosceptics in his party that he had a tough and firm stance on the European issues. Later on, instead of voting against Dehaene, the British prime minister held his threat and employed the veto. Consequently, using the ultimate weapon of veto for party political purposes was a significant moment for the Britain- EU relations. John Major ignored the unwritten rules of the EU (Watts \& Pilkington, 2005).

When there was progress towards EMU at Maastricht, Major government's approach was wait-and-see. Under EMU it planned to create three institutions: the European Central Bank (ECB), the European System of Central Banks (ESCB), and a common currency. However, among all the integrationist steps, eurosceptics were most suspicious of the EMU institutions. Britain refused to commit itself to a target date to join the single currency for several reasons. First, it was difficult to estimate when the British economic cycle and the other EU economies were going to converge enough. Second, there was uncertainty about how much time was needed to complete the economic and political prerequisites. Third, the government did not want to make a decision until there was sufficient information about the functioning and the impact of euro. Therefore, the government implemented a policy that a judgment on entry would be made if the euro became successful or not, and if the five economic tests of the Chancellor, Gordon Brown were satisfied (Gowland \& Turner, 2000; Watts \& Pilkington, 2005). Brown's five economic tests for the adoption of single currency were the following questions: 
Would it help to create jobs? Would it promote investment in the UK? Would it be of assistance to the City and the financial services sector? Was the EU economy strong and flexible enough to withstand any shocks that might arise if there was a single currency? Was the British business cycle in harmony with those of other member states? (Gowland \& Turner, 2000, p. 349).

Lastly, senior ministers were aware of the political risks of giving an unambiguous commitment to join the single currency area (Gowland \& Turner, 2000).

After Labour's 1997 victory, Tony Blair signaled that the UK government was going to be less obstructionist in the EU compared to the former governments; however, Blair government also became defensive on issues of further integration. When Tony Blair came to power, he gave the message that he would like Britain to take a constructive role in Europe. His government gave the hint that instead of confrontation, they are willing to negotiate and readily compromise. However, when German finance minister, Oskar Lafontaine, outlined proposals for tax harmonization, Blair government got defensive. The British tabloid press was fiercely against such European initiatives. Due to the hostility pumped by the media, ministers took a more anti-European stance. Tony Blair and chancellor Gordon Brown stated that they would veto any harmonize or expand in European taxation. As a result, Tony Blair avoided majority voting on direct taxation and social security during the Nice Summit in 2000 (Watts \& Pilkington, 2005).

After the European debt crisis, the attitude of the UK hampered the process of taking necessary precautions. At the European Summit of January 2012, except the Czech Republic and the UK, EU member states agreed on a fiscal treaty which will enforce budget discipline. A binding treaty that enforced budget rules was particularly important for Germany, which is the Eurozone's most powerful economy and the biggest lender. The purpose of the German leadership was to prevent the accumulation of excessive 
debts by closer co-ordination of budget policy across the EU. By monitoring compliance and imposing fines on rule-breakers, the fiscal treaty empowers the European Court of Justice. Additionally, scrutinizing national budgets, the treaty enhances the role of the European Commission. However, the UK Prime Minister David Cameron rejected the deal claiming that proposals for financial service regulations would affect the City of London. As a result, by prioritizing Britain's interests over every European matter, Cameron disregarded taking necessary fiscal measures to prevent any future crisis that would especially make the Eurozone countries suffer ("EU summit: UK and Czechs refuse to join fiscal compact," 2012, "Q\&A: EU fiscal treaty to control eurozone budgets," 2012; Nielsen, 2012). 


\section{Benefits \& Costs}

The costs of EU membership are another dimension of Britain's dissatisfaction. The costs of EU membership that have become controversial for Britain contain the common agricultural and fisheries policies, EU-wide regional funds, contributions to the EU budget, and the implementation of EU social and employment regulations at the UK economy. Deepening of political integration in the form of qualified majority voting, European Court of Justice jurisdiction and the increased powers of the European Parliament caused the shift of more democratic control to Brussels. On the other hand, if Britain leaves the EU, there would be significant costs of leaving the membership in terms of trade, foreign direct investment, international negotiations and other non-trade factors. Consequently, this section of the paper presents the current cost-benefit analysis in the literature aiming to understand economic and political impacts if Britain leaves the EU both from the perspectives of the UK and the EU.

\section{UK's Trade with the EU}

According to Stephen Booth and Christopher Howarth (2012), the EU and especially the eurozone continue to be the most important trade market for the UK. First of all, the EU accounts for a significant amount of the UK's trade. $47.5 \%$ of the UK's total goods and services exports is with the EU (Brocklehurst et al., 2012). Being a member of the EU, Britain enjoys the tariff free single market. With the enlargement of the EU, the UK has been able to benefit from the expanded internal market. Additionally, due to the Europe-wide standards of the Single Market, UK firms must comply with only one set of specifications. Complying with a single set of regulations decreases the costs of the firms (Booth \& Howarth, 2012). 
Graph I: UK's trade in goods \& services 2011

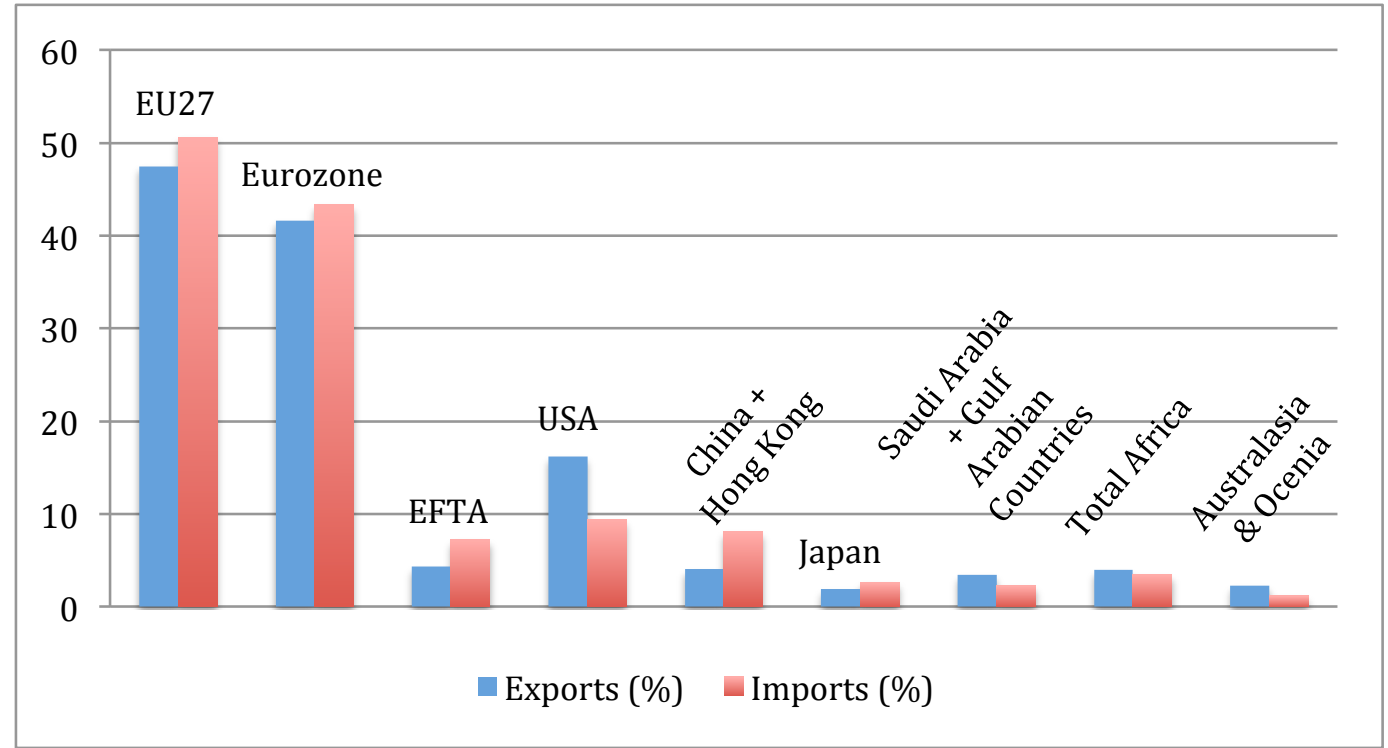

Source: Pink Book 2012 - Chapter 9: Geographic breakdown of current account

Booth and Howarth (2012) point out four important facts that need to be taken into account in Britain's trade with the EU. First, the Rotterdam-Antwerp Effect causes distortions to the UK's goods and services exports to the EU. Rotterdam in the Netherlands and Antwerp in Belgium are two substantial ports in the world that handle large amounts of exports coming from Britain. Some of the British exports are consumed in Belgium and Netherlands; however, some of them are continued to be shipped by road and rail to other EU countries, and some of these exports are shipped onwards to other continents by cargo vessels. In other words, even if the British exports are shipped to the Netherlands and Belgium, some of these exports are transshipped to other EU countries and other continents from the ports of Rotterdam and Antwerp without even touching Dutch or Belgian soil. As a result, compiling the geographical export registers by the British Office for National Statistics, the Rotterdam-Antwerp Effect occurs due to recording the first port of the discharge of consignment as the geographical destination of 
the export even though that is not the end-destination country for the consignment ("The Rotterdam-Antwerp Effect \& the Netherlands Distortion,” 2011).

Second, due to the Netherlands Distortion, all earnings in the UK from FDI coming from the EU are overstated. Global Britain Briefing Note explains the Netherlands Distortion:

For tax reasons, FDI is often channeled through intermediate holding companies domiciled in the Netherlands. In collecting statistics on FDI involving the UK, the Office for National Statistics (ONS), ... records such FDI as originating in or going to the Netherlands, rather than the country of ultimate origin or the country which is the end-destination of the FDI. The resulting Netherlands Distortion affects geographical analyses not just of FDI flows, but of the income or earnings (in the form of profits, dividends, interest and management fees) associated with them ("Foreign Direct Investment: The Netherlands Distortion," 2004; p. 2).

The Rotterdam-Antwerp Effect and the Netherlands Distortion can be demonstrated by a simple calculation using the current account data. The impact of both the Rotterdam-Antwerp Effect and the Netherlands Distortion can be seen in current account credits because it is formed of export of goods, export of services, income and current transfers. As the size of these distortions can be seen at Table I, a Dutch person is consuming British imports approximately five times more than a German or a French person; a Belgian person consumes about three times more than a German or a French person; and a Luxembourger consumes more than 50 times. According to on the ground observation, the per-capita consumption of British imports is mainly the same in Germany, France, the Netherlands, Belgium and Luxembourg. Therefore, compared to Germany and France, the excess consumption of the British imports in the Netherlands, Belgium and Luxembourg embody the Rotterdam-Antwerp Effect and the Netherlands Distortion (“The Rotterdam-Antwerp Effect \& the Netherlands Distortion,” 2011). 
Table I: The Rotterdam-Antwerp Effect \& The Netherlands Distortion

\begin{tabular}{|l|l|l|l|l|l|}
\hline & Germany & France & Netherlands & Belgium & Luxembourg \\
\hline $\begin{array}{l}\text { A: } 2011 \text { Current } \\
\text { account credits } \\
\text { (£ million) }\end{array}$ & 52914 & 42435 & 51427 & 22404 & 17710 \\
\hline $\begin{array}{l}\text { B: } 2011 \text { Population } \\
\text { (million) }\end{array}$ & 81.7 & 65.4 & 16.7 & 11.0 & 0.5 \\
\hline $\begin{array}{l}\text { A/B UK current } \\
\text { account per capita } \\
(\text { () }\end{array}$ & 647.5 & 648.5 & 3080.2 & 2035.2 & 34255.3 \\
\hline \begin{tabular}{l} 
1: Source: ONS Correction The Pink Book 2012 \\
\hline 2: Source: World Bank World Development Indicators
\end{tabular} \\
\hline
\end{tabular}

If the per capita consumption of British imports is roughly the same in Germany, France, Belgium, the Netherlands and Luxembourg, the accurate amount of British imports consumed by Dutch, Belgian and Luxembourger people can be calculated. Similarity in the per capita consumption, it can be assumed that the average value of German and French per capita imported British goods, services and income $[(647.5+648.5) / 2=648]$ is the same for a Dutch, a Belgian and a Luxembourger. By using the average per capita consumption in Germany and France, the current account credits coming to Britain from the Netherlands, Belgium and Luxembourg can be calculated.

Table II: The UK Current Account: real versus officially recorded in 2011

\begin{tabular}{|l|l|l|l|}
\hline$£$ million & Real ${ }^{*}$ & Official & Excess \\
\hline To Netherlands & 10819 & 51427 & 40608 \\
\hline To Belgium & 7133 & 22404 & 15271 \\
\hline To Luxembourg & 335 & 17710 & 17375 \\
\hline Total & 18286 & 91541 & 73255 \\
\hline $\begin{array}{l}\text { * assuming per capita imports of British goods, services \& income in each } \\
\text { country is £ 648 }\end{array}$
\end{tabular}

Since the excess amount is not totally coming from the other EU countries but also from the non-EU countries that are transshipped from Rotterdam and Antwerp, it can be assumed that only half of the total current account excess amount ( $£ 73$ billion) comes 
from $\mathrm{EU}$ countries. According to this assumption, there is approximately $£ 37$ billion excess amount in the current accounts that are recorded as originating from EU countries, but actually originated from non-EU countries. As a result, the total amount of the current account credits of Britain from the world will not change. However, the share of credits from EU countries has decreased from $44.5 \%$ to $39.2 \%$. Furthermore, 37 billion $£$ excess amount accounted for the EU means that Britain's Office for National Statistics displays the 2011 current account credits of the EU in Correction The Pink Book 2012 11.8\% more.

For the third fact about Britain's trade with the EU, Booth and Howarth (2012) point out that Britain is less dependent on the EU for trade than other EU countries. Even though the EU and the Eurozone are the largest markets for Britain's trade (Graph I), the UK is less reliant on the EU than the most of the other members in terms of trade (Booth \& Howarth, 2012). As seen from Graph II, the UK is at the low end of the chart with countries whose intra-EU trade has a small share in their total goods exports. Malta and Greece's exports to the EU in their total exports are $34.4 \%$ and $40.6 \%$ respectively. The UK is following these two with $47.8 \%$ share of EU goods exports. On the other hand, countries like Luxembourg, Czech Republic and Slovakia export around $80 \%$ of their total exports to the EU. The farther to the right hand side of the chart, the more dependent the member countries are to the EU market. 
Graph II: Share of the merchandise exports to the EU in total exports (\%) - 2012

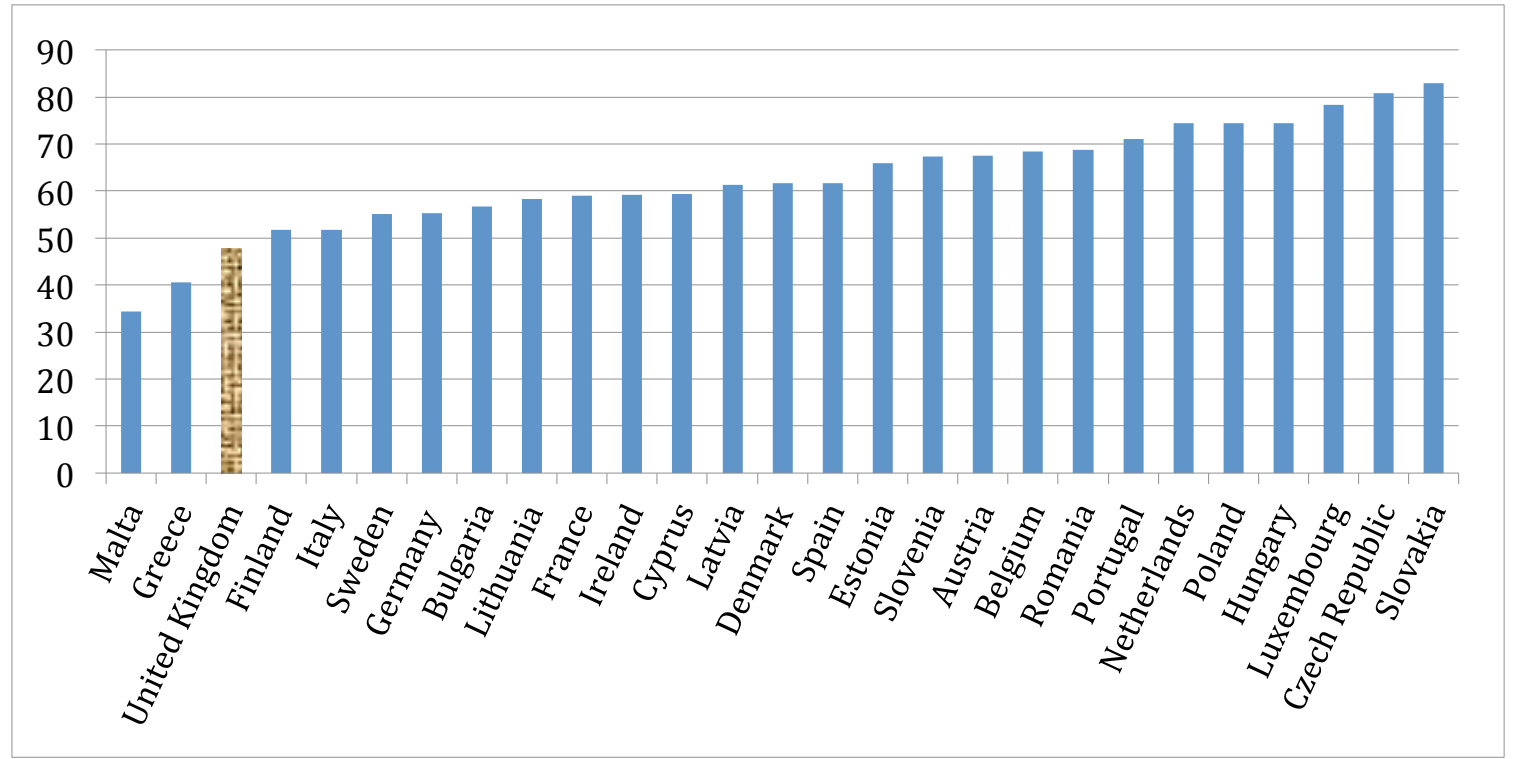

Source: Eurostat 2013

The price of leaving the Single Market for the UK today is much smaller than the time when it joined the union in 1973. The tariff barriers all over the world have been decreasing due to the negotiations of GATT and its successor WTO ("Britain and Europe: Making the Break,” 2012). EU tariff rates have followed the global trend as it can be seen from Graph III (Booth \& Howarth, 2012). "If import tariffs are weighted by the volume of trade in each product, the average faced by exporters from outside the EU into the [S]ingle [M]arket has fallen to around 3\%" ("Britain and Europe: Making the Break," 2012, par. 20). This much of a cost increase is normal for exporters due to the rise in oil prices and sudden changes in the exchange rates. However, in certain areas, such as agriculture, automotive, and textiles, EU tariffs are comparatively high (Booth \& Howarth, 2012). 
Graph III: EU's average MFN tariff rates in all products (\%)

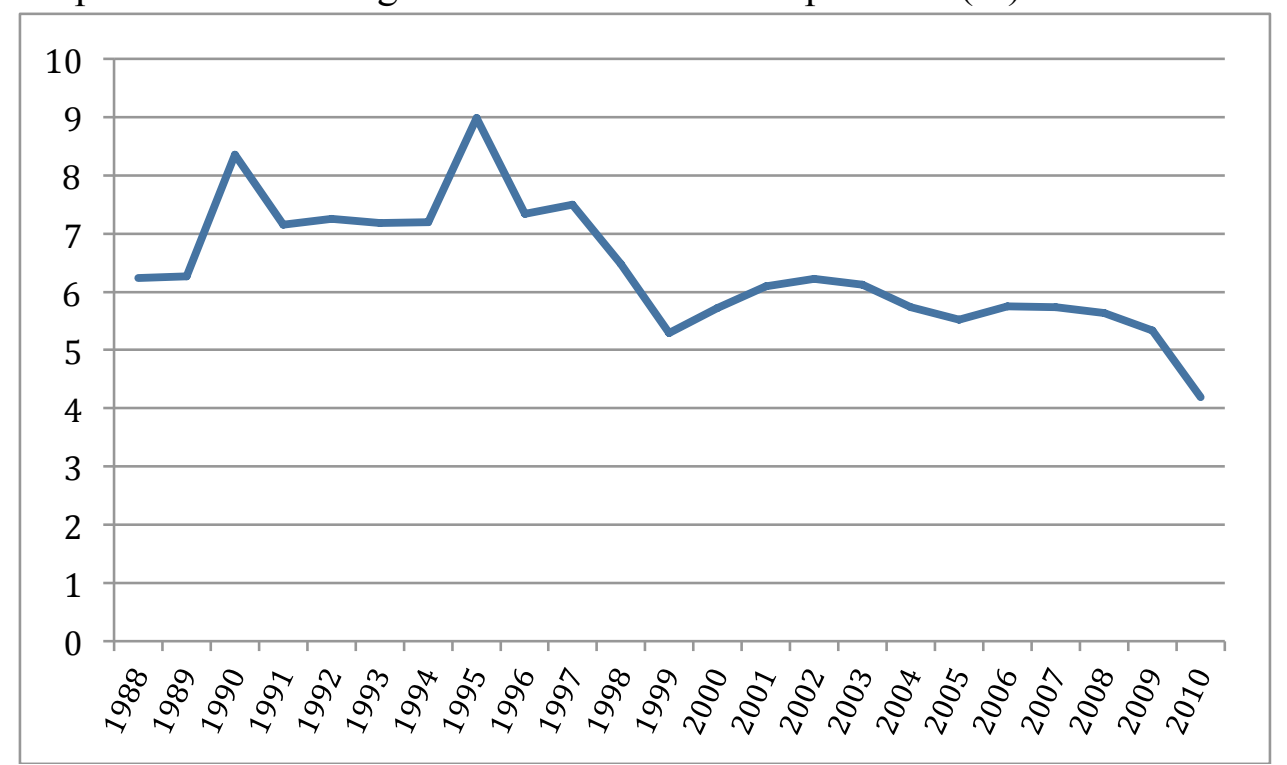

Source: World Development Indicators 2013

In industries such as food and textiles, the impact of leaving the Single Market would be harder for the UK. British dairy exports would be exposed to an import tax of $55 \%$ and tariff rates higher than $200 \%$ for certain items. For instance, cheddar cheese would incur a tariff of $€ 167$ per $100 \mathrm{~kg}$ and for Stilton the overhead would be $€ 141$. As it can be seen at Graph IV, the average MFN tariff rate for dairy products is $32.6 \%$. In clothing the average tariffs would increase the price of British exports up to $12 \%$ in European markets. Furthermore, for non-agricultural products such as motor vehicles and fish, the EU tariff rates can be as high as $22 \%$ and $22-26 \%$ relatively ("Britain and Europe: Making the Break,” 2012; WTO Secretariat, 2011). 
Graph IV: EU simple average MFN tariff rates 2011

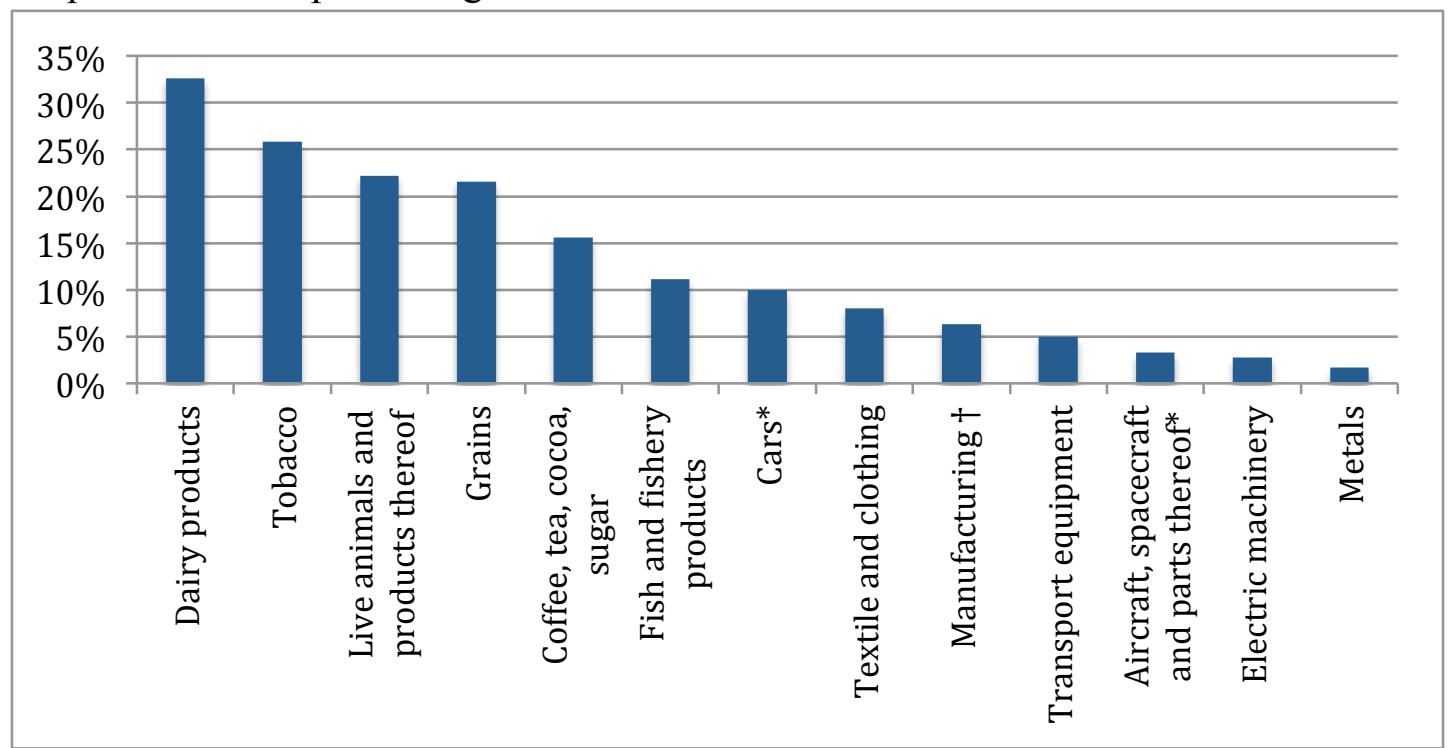

* HS07 - Harmonized commodity description and coding system the data used are the average of all ad valorem duties

$\dagger$ ISIC - International Standard Industrial Classification (Rev.2)

Source: WTO Trade Policy Review WT/TPR/S/248 \& WTO Trade Download Facility 2013

In a scenario of leaving the EU, Britain's car industry would be negatively

influenced. First of all, British car exports to EU countries would be facing an average of $10 \%$ ad valorem MFN duties (Graph IV). Moreover, there would be a tariff rate of $4 \%$ on the car equipments entering the EU market, and there would be pressure in Britain to apply tariffs on parts imported from the EU. Particularly, plants and supply chains of car producers in other EU countries would be under high risk. When car components leave the continent, their passing might be blocked or delayed ("Britain and Europe: Making the Break,”2012).

Aerospace is another industry which requires uninterrupted trade with the continent. Being the world's largest industry outside the US, if Britain walks away from the EU, France will take its place. It will take some time to produce high-tech materials such as carbon fiber wing spars in different places. However, the production of basic 
components, like metal brackets, can easily be replicated elsewhere. To keep their supply chains simple, large manufacturers, such as Airbus might support new suppliers in the EU to evade customs barriers ("Britain and Europe: Making the Break," 2012).

Lastly, Booth and Howarth (2012) highlight the significance of the services sector for the UK. As it can be seen from Graph V, the services sector has a positive impact on the UK trade balance while trade in goods increases the deficit of the balance of payments. Especially, financial services have the largest share in UK's services exports. According to the ONS in Correction The Pink Book 2012, 50.6\% of the surplus in the services trade is due to the financial services (Brocklehurst et al., 2012). As it can be seen from Graph VI, the UK is the second most benefiting country from financial transactions in the world after the US. In 2011 the net balance of the US and the UK from financial transactions were 42 and 38 billion Euros respectively, while the closest country to these two was Luxembourg with only 15 billion Euros.

Graph V: UK's trade balance in goods and services 1970-2011 (bn £)

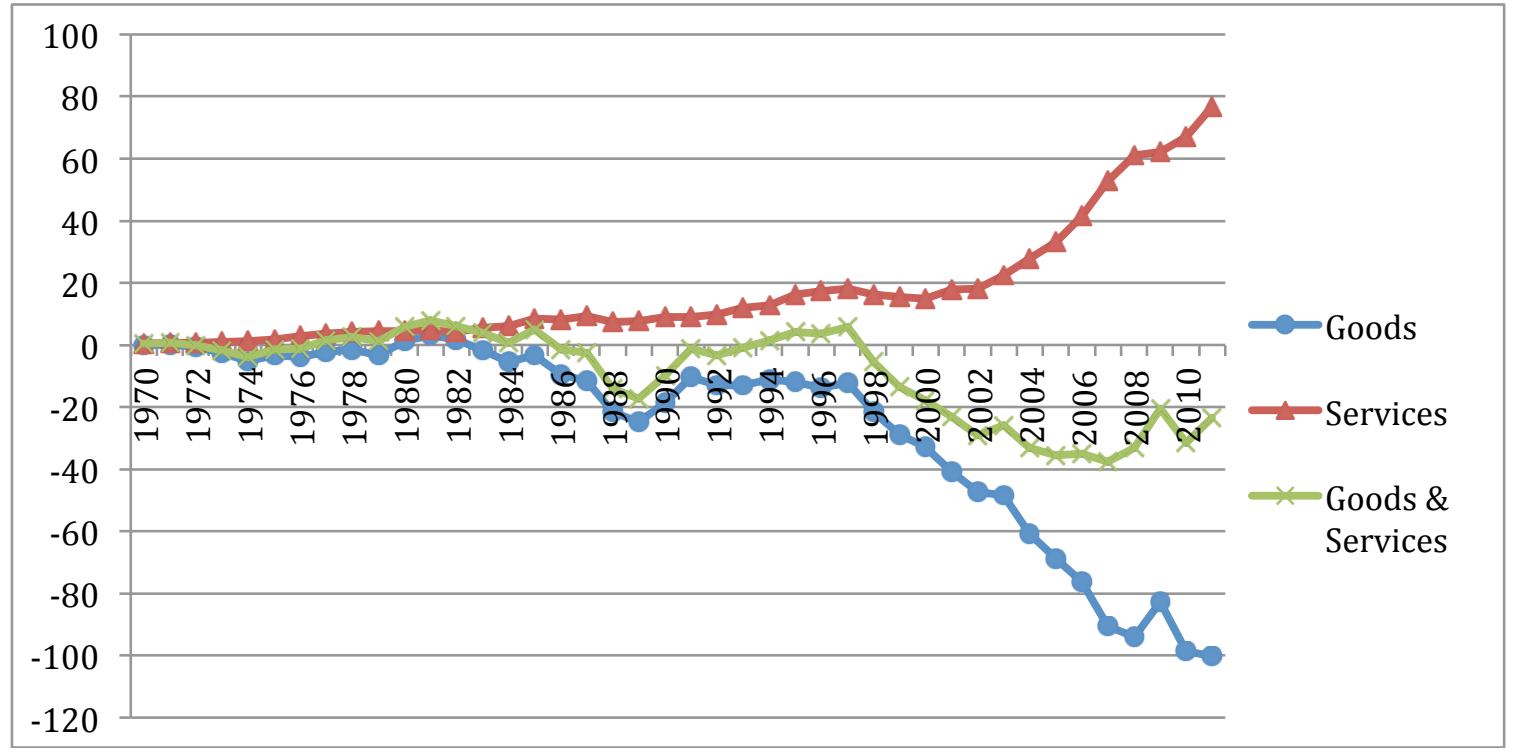

Source: ONS Balance of Payments, Q3 2012 Dataset 
Graph VI: 2011 International transactions in financial services: balance (bn €)

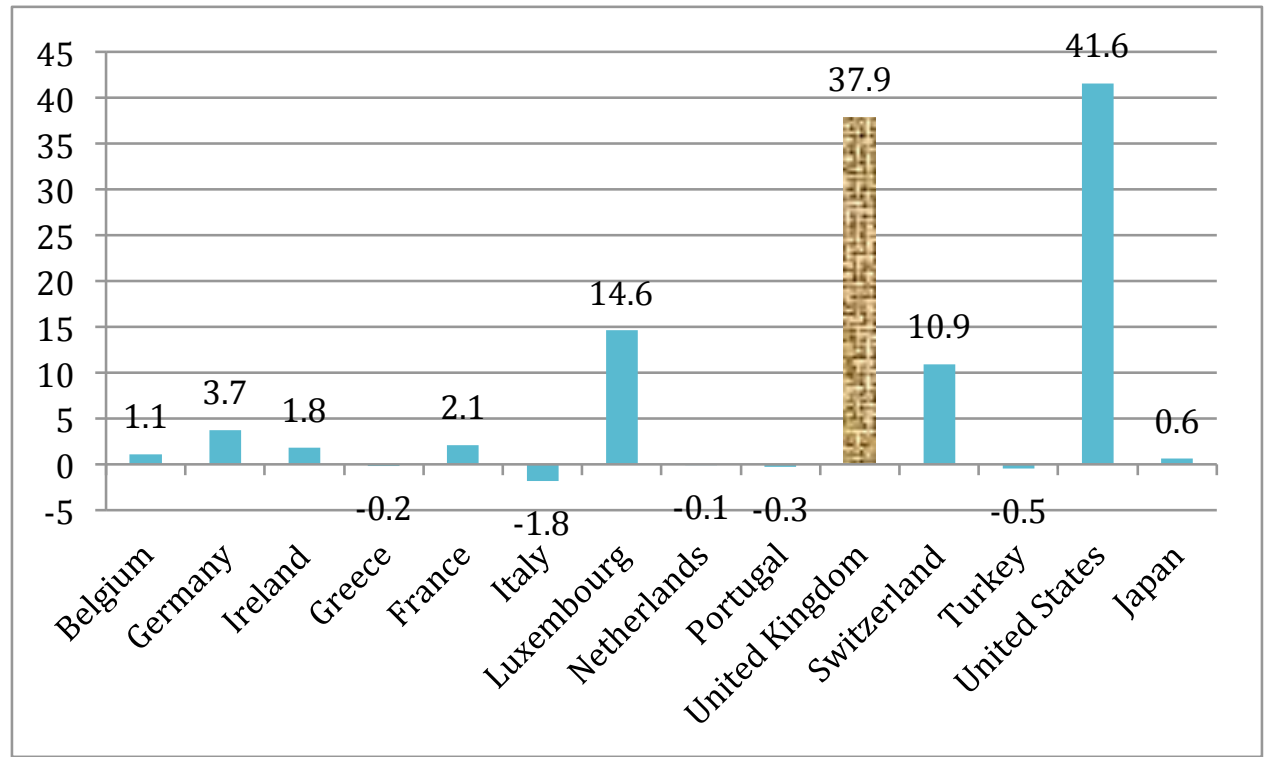

Source: Eurostat 2013

Due to the limited liberalization of the services trade in the EU Single Market, the UK has not been able to benefit enough from the market even though the services sector is its strong suit. According to the National Accounts data of Eurostat (2013), services have the highest contribution to the EU-27's total gross value added. The share of services in the EU-27's total gross value added raised from $70.2 \%$ in 2001 to $72.5 \%$ in 2011. Especially in Cyprus, Malta, France (2010 data), Greece, Belgium, Denmark and the United Kingdom, services consisted more than three quarters of their total value added ("National accounts - GDP," 2013). As it can be seen at Graph VII, the EU is the biggest trade destination for UK services exports. However, UK's level of services export to the EU-27 is much below the level of goods exports (Graph VIII). UK's services export to the rest of the world is increasing faster than its services export to the EU-27. 
Graph VII: UK’s services exports by destination 2011 (bn £)

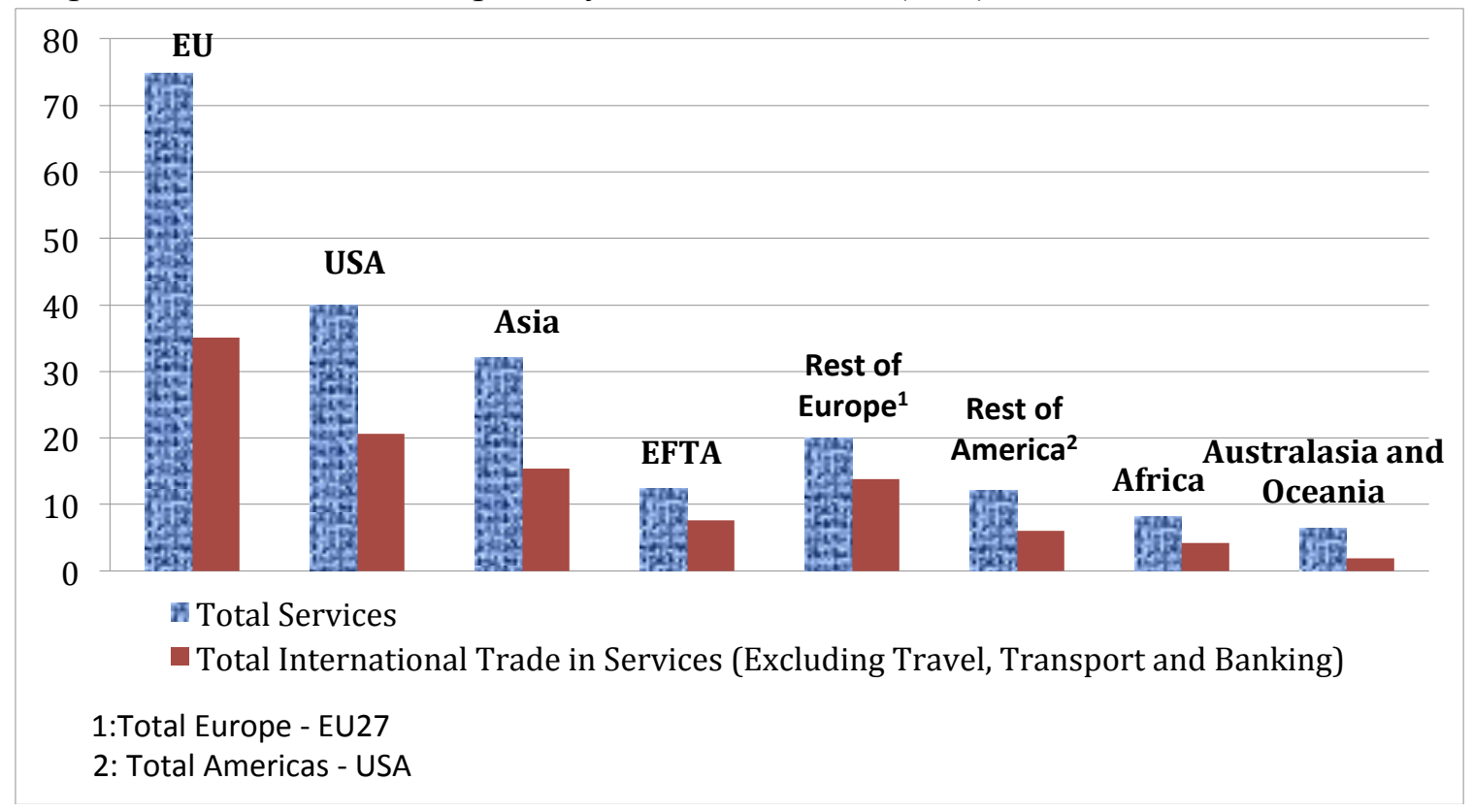

Source: ONS Correction The Pink Book 2012 \& ONS International Trade in Services

Graph VIII: UK exports: EU vs. rest of the world

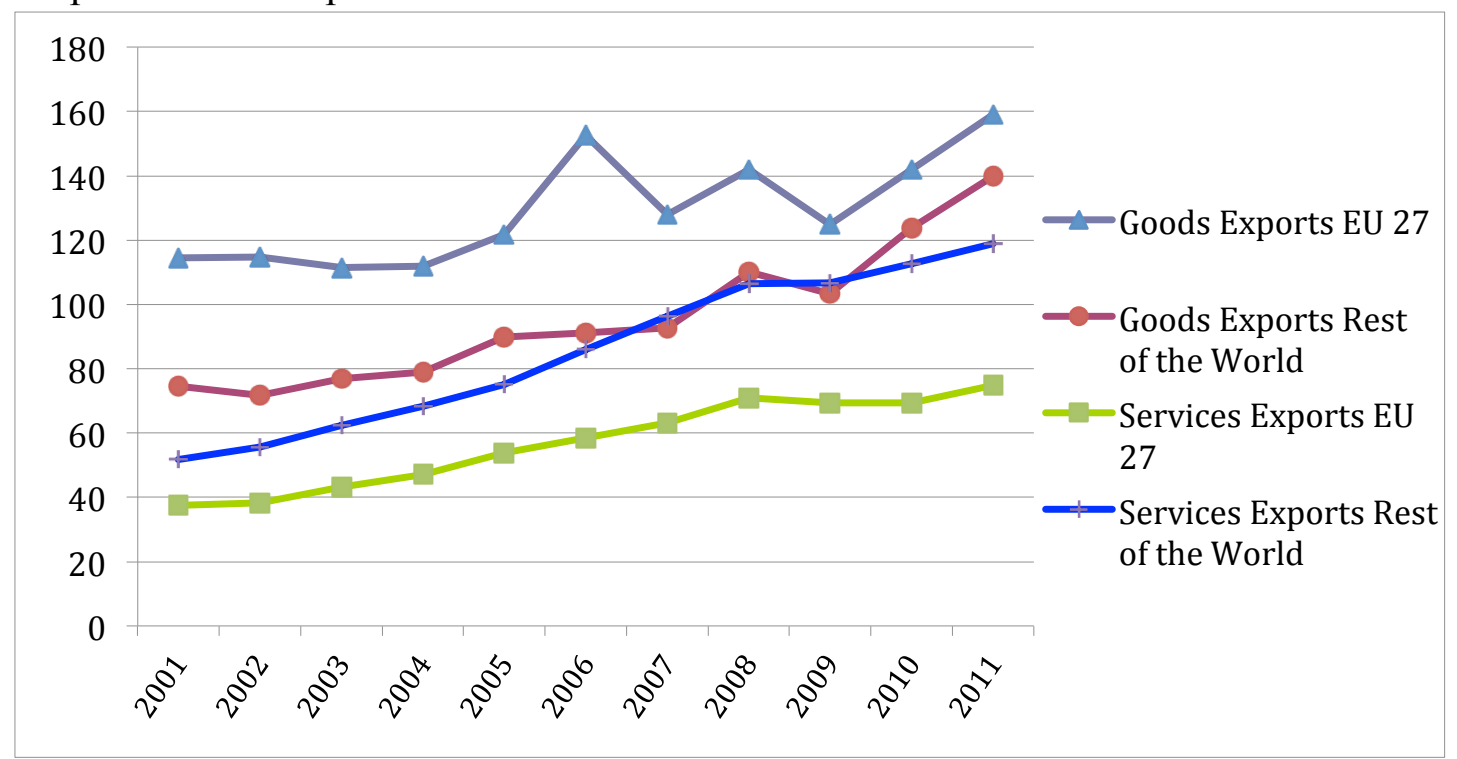

Source: ONS Correction The Pink Book 2012

If Britain leaves the EU, the business investment on finance would drift away to the continent. Today, the financiers of the rising economic powers of Asia and Latin America are more interested in the European market than the American banks that were interested in London due to the loose regulations in the 1950s and 1960s ("Britain and 
Europe: Making the Break," 2012). According to the report of TheCityUK, the analysis of 147 location decisions of financial services firms between 2006 and 2012 indicate that $40 \%$ of the decision makers mentioned the European Union as the main reason for choosing Britain (“Amber warning,” 2012). Even though trade liberalization in financial services is limited in the Single Market, banks, investment and insurance companies based in the UK have the ability to set up branches or make service available all around the EEA. Therefore, keeping its position as the primary center for sorting out cash trades and derivatives in euros is the only way for London to become a regional hub, and trade China's currency ("Britain and Europe: Making the Break,” 2012).

\section{Foreign Direct Investment Received by the UK}

It is difficult to assess the amount of inward investment the UK is attracting because of its EU membership. Due to various reasons, such as the English language, infrastructure, laws, innovation, and being in the Single Market, the UK has been able to attract significant amounts of inward investment. As it is indicated in Graph IX, after the Single European Act (1986) and the Maastricht Treaty (1993) the flow of investment into the UK increased. However, when the FDI inflow of the UK is compared with the US and the EU's total, we see similar trends. Therefore, some of the increase in the UK's FDI is not totally related to its EU membership, but also to global factors, like the 'dotcom bubble'. In spite of the global factors, some sectors, such as the car industry, have overseas investments in the UK, primarily due to the Single Market (Booth \& Howarth, 2012). Therefore, if Britain leaves the EU, Japanese carmakers would be hurt because most of their British production is sold in the EU market ("Britain and Europe: Making the Break," 2012). 
Graph IX: Foreign direct investment, net inflows (\% of GDP)

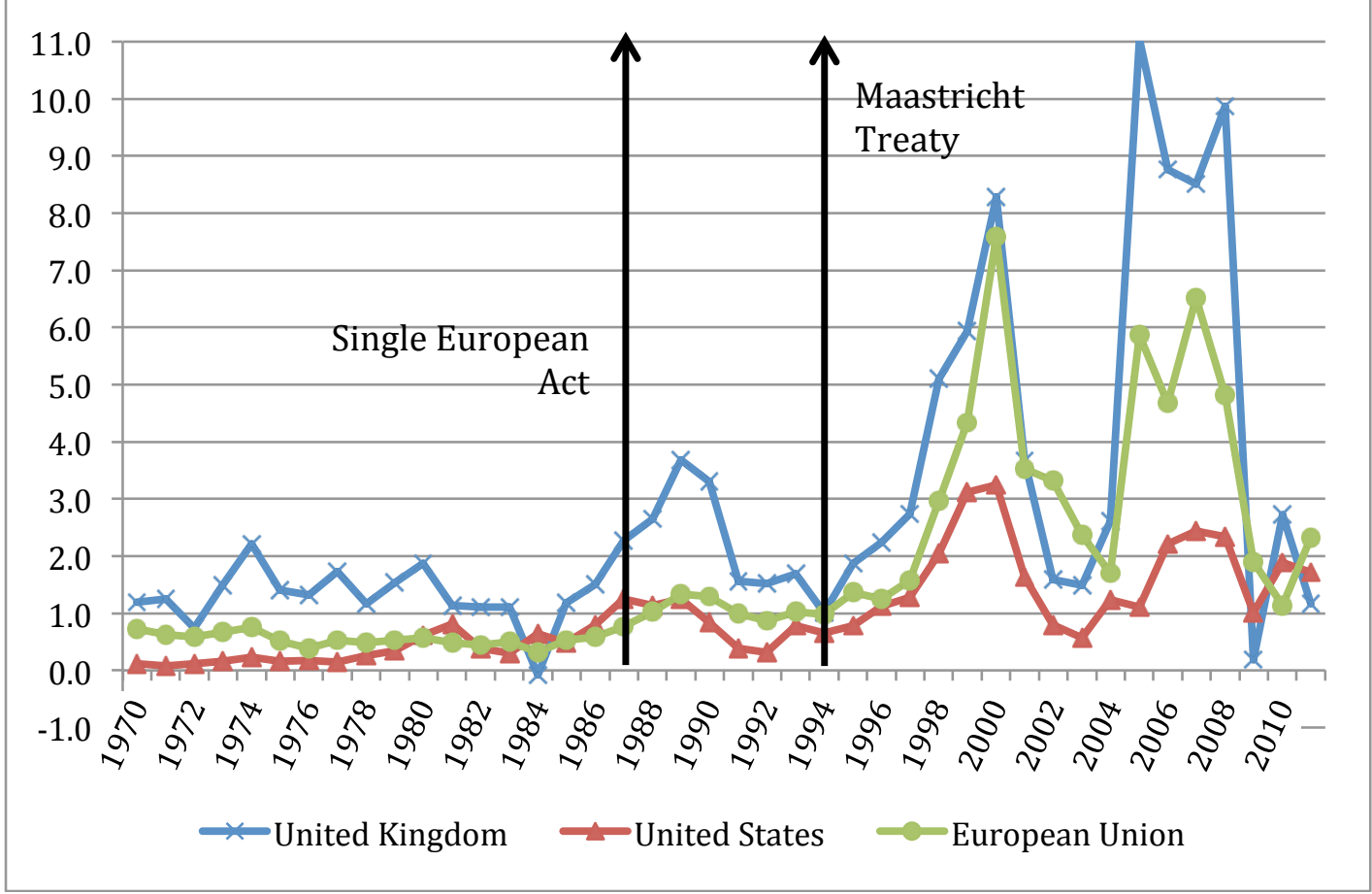

Source: World Development Indicators 2013

If Britain leaves the EU, the British car industry, which is the engine of its economy, is going to suffer a blow. Paul Haydon points out that despite the impact of the European financial crises, there is rapid growth in output and productivity in the British car industry (2013). In 2012, Britain exported more cars than it imported since 1976. In the first quarter of 2012, the trade surplus in cars increased the total goods export of the UK by $5.8 \%$, making it $£ 26.4$ billion (Rowley, 2012). By offsetting Britain’s large trade deficit and accounting for $11 \%$ of its manufactured exports, the automotive industry is vital for the British economy. The performance of the British car industry is not only resisting the relative economic decline but also reinstating the Britain's position as a global manufacturing hub. According to Haydon (2013), increase in foreign direct investment, international trade and innovation are the main reasons of the revival of the British car industry. Britain's EU membership is crucial for each of these factors. The 
British automotive industry received nearly $£ 6$ billion in foreign direct investment over the last two years. "This investment has been primarily motivated by the UK's position as a [launch pad] into the highly regulated EU market" (Haydon, 2013, para. 3). Even the EU-South Korea trade agreement, which was signed in 2012, increased the vehicle exports from the UK by $8 \%$. The recent trade agreement with Singapore is also expected to increase British car exports. If Britain leaves the Single Market, car makers such as Nissan, Ford and BMW would shift their investments to more secure EU countries like Poland or the Czech Republic. Unrestricted access to the Single Market would be highly unlikely even if the British government renegotiates a unilateral free trade agreement with the EU. As result, accompanying uncertainty would make the investors look for alternative countries ("Britain and Europe: Making the Break," 2012; Haydon, 2013; Wheeler \& Peter, 2013).

\section{Negotiation Power of the EU}

According to Booth and Howarth (2012), with the combined economic capacity of its members, the weight of the EU can function as leverage for the interests of the UK in international trade talks. Uniting all of its members, the EU is world's largest economy and trading block with a total population of over 500 million. The EU holds nearly $29 \%$ of global output, $15 \%$ of global merchandise exports (2011) and $25 \%$ of global commercial services exports (2011) (“Trade Profiles: European Union (27),” 2012). Having such a large domestic market gives a negotiation advantage to the EU since it has the ability to hold back or revoke the access of its trading partners. As a result, having the ability to influence global trade talks, the EU market clout can be a means to further the UK's interests in global trade talks (Booth \& Howarth, 2012). 
The EU has been able to use its weight during the negotiations with the US and China, which would be very difficult for the UK alone. For instance, due to the EU support, after a series of talks, EU companies doing business in China gained protection of their intellectual property rights. The EU also negotiated for EU companies to have access to the public procurement system of China. Other examples are the negotiations between the EU and the US on air travel and steel tariffs. The combined weight of the EU most likely helped in all these negotiations to be better off in outcomes that would be difficult for the UK to obtain alone (Booth \& Howarth, 2012).

On the other hand, due to the aggregation of all the member states' national interests, the EU can act against the interests of the UK in certain issues. For instance, the UK supported the EU's efforts to expand trade concessions for Pakistan due to strategic, commercial, and cultural reasons. However, some other EU countries that are concerned of Pakistan accessing the EU's textile market voiced their opposition, such as Portugal, and slowed down the negotiations. Similarly, in EU's negotiations with Singapore, other EU states' interests are prioritized over the UK interests. Being a major financial services market, Singapore is a significant market for UK services exports. However, since Singapore has zero tariff rates, negotiating just for non-tariff barriers and have an agreement was not in the interest of other EU countries that would like to protect their goods (Booth \& Howarth, 2012).

\section{Non-trade Costs and Benefits of EU Membership}

Since the EU is more than a trade organization, there are non-trade costs and benefits of membership. One of the most important costs of EU membership is the loss of national democratic control. Due to the Qualified Majority Vote (QMV) in the EU 
decision-making process, the UK can be outvoted or might have to concede before voting. Further losses in national political control should be expected because of the increasing power of the European Parliament and the jurisdiction of the ECJ. The UK is influenced by the loss of national political control in many areas, but especially in financial regulations where it has compelling economic interests. Additionally, justice and home affairs regulations have repercussions on the criminal justice and asylum system of the UK. Moreover, the EU brings significant regulatory costs to the UK. Particularly social, employment, health, and safety regulations of the EU, such as the Working Time Directive (WTD) and the Agency Workers Directive (AWD) bring cost burden to UK businesses and to the public sector (Booth \& Howarth, 2012). According to a study which analyzes more than 2,300 impact assessments, and published by Open Europe in 2010, the cost of EU regulations to the UK economy was $£ 124$ billion since 1998 (Gaskell \& Persson, 2010).

Having a very different agriculture and farm policy than other member countries, EU budget contributions have brought significant costs to Britain. The agriculture and farm policies of the EC countries were very different than the British domestic agriculture policy. Having access to the cheap food supplies of the Empire or the Commonwealth, the British agricultural policy was oriented towards cheap prices. On the contrary, in the original six countries the agriculture policy was producer-oriented because the share of agriculture in GNP and employment was much higher in the postwar period. As a result, the CAP negatively influenced Britain's integration. Due to the bias of CAP towards spending on agriculture, Britain was not financially benefiting from the budget. Therefore, the British government looked towards changing the budgetary 
system to be able to account for the circumstances of the UK. For the UK, EU budget contributions are expected to remain around £14bn mostly due to CAP and EU regional policy reform. Besides regulating all the waters of the member states, Common Fisheries Policy has been negatively influencing the fisheries and the fishermen in the UK (Booth \& Howarth, 2012; Bulmer, 1992).

Through the European Political Co-operation British foreign policy benefited from the European integration in two ways. In 1970s Britain realized that its channels to play a world role became very limited. Neither its special relationships with the US nor its traditional connections with the Commonwealth was reliable for British foreign policy anymore. In that era, the European Political Co-operation (EPC) provided a third alternative for the British foreign policy. Additionally, being a part of the EPC, Britain was able to use the developing West European foreign and defense policy in 1990s as a channel (Bulmer, 1992).

The main non-trade benefit of EU membership for the UK is to be able to affect political and economic events in Europe. Being a member, the UK was able to champion the development of the Single Market in goods, and now it is pushing for the liberalization of the services. Furthermore, EU membership allowed the UK to support the enlargement of the union to the East, and the UK will be a part of the decision making for the future enlargements. Additionally, by contributing to the EU foreign policy as a major military power, the UK has the ability to play a role in Europe's global relations (Booth \& Howarth, 2012).

If Britain leaves the EU, it would lose its diplomatic and military sway. A Britain which is detached from the Europe would be a less valuable ally to the US because of 
losing its functionality. Moreover, a Britain that is disengaged from the rest of Europe would erode the continental ties in NATO. These ties are already under tension due to the decreased defense budgets and the "rebalancing" strategy of the US against Asia (“Britain and Europe: Making the Break," 2012; Wheeler \& Peter, 2013).

Another issue that would affect Britain negatively is the reallocation or repatriation of people. Leaving the EU means that there is going to be barriers against the free movement of labor. However, in 2011 there were 2.3 million people living in Britain from other EU countries and 1.7 million British people in other EU countries. The residential rights of these migrants would be a problem if Britain leaves the EU. In case of a forced repatriation all countries would suffer. Once the walls of the borders are risen up, the businesses would be harmed. For instance, London's expanding tech industry and the City benefit highly from the flow of young workers coming from the other EU countries ("Britain and Europe: Making the Break," 2012).

\section{UK's Importance to the EC}

EC and EPC have played significant roles in British policy, however, Britain's role in the European integration was very limited. First, Britain was not one of the six which initiated the European integration. The integration progressed two decades without British involvement. Second, the disagreements of Britain in the EC, such as the budgetary contribution and the CAP created doubts in other member countries about Britain's commitment. Moreover, Britain blocked the attempts to strengthen the supranational institutions of the EC, like establishing a uniform electoral system for the European parliament. Britain was reluctant to participate in some policy areas, and the European Monetary System was the most well known among them. European initiatives 
have often been from the Franco-German core or the European Council but not from the commission. In other words, governmental initiatives have hardly ever come from the British government (Bulmer, 1992).

The contribution of Britain to the European integration was only in two specific areas. First, Britain's diplomatic resources, such as its connections with the US and the Commonwealth, helped the development of political cooperation significantly in the EPC. British contribution can be seen in the European integration is and related to the liberalization and deregulation of the internal market. In this regard, during the British presidency of the Council of Ministers in 1981, the service sectors were brought into attention. The Thatcher government advocated the measures to include the service sectors in the internal market (Bulmer, 1992). 


\section{Analysis}

In this section, by using a conflict-cooperation analysis under Power Transitions perspective, an empirical assessment will be made to understand the influence of the UK on the European integration process. Analyzing the relationship between relative power, hierarchies and the level of satisfaction, Power Transitions measures conflict and cooperation.

As the first step of the conflict-cooperation analysis, it is significant to understand the hierarchy of the European Union. Power Transitions teaches us that the influence of every nation in the international system is not constant. Some nations in the international system exert more influence to the status quo than others. Related to their level of power, countries become more capable in influencing the global or regional status quo. Countries' level of economic, political, military, demographic and technological capabilities compose their level of power. In the European hierarchy, level of power will be accounted by the measurements of GDP purchasing power parity (PPP), the population and Composite Index of National Capability Score. Composite Index of National Capability Score is the sum of six capability components, which are total population, urban population, iron and steel production, energy consumption, military personnel, and military expenditure (Singer, 1987).

The UK is among the great powers of European hierarchy. Using three measurements of power, GDP, population and Composite Index of National Capability Score, Graph X depicts the hierarchy of the European Union. While Y-axis indicates the level of GDP and X-axis shows population, the size of the bubbles demonstrate the Composite Index of National Capability. According to Graph X, Germany is clearly the 
regional leader. Though the UK has the second highest GDP in the Union, France and Italy are close to the UK. Therefore, the UK, France, and Italy can be identified as great powers. Due to their economic, demographic, and military capabilities, Spain, Poland, Austria, Netherlands, Belgium and Sweden can be identified as middle powers. Due to the number and variety of members, it is not figurative to show all 27 members of the Union in one graph. For simplicity, Graph X depicts the member countries whose GDP level is higher than $\$ 600$ billion. The rest of the member countries' level of GDP vary from $\$ 253$ billion to $\$ 10$ billion, and can be categorized as small powers. In terms of their level of power, from the highest GDP to the lowest, small powers of the EU are as follows: Czech Republic, Greece, Romania, Portugal, Denmark, Finland, Hungary, Ireland, Slovakia, Bulgaria, Lithuania, Slovenia, Luxemburg, Latvia, Estonia, Cyprus, and Malta. 
Graph X: Hierarchy of European nations

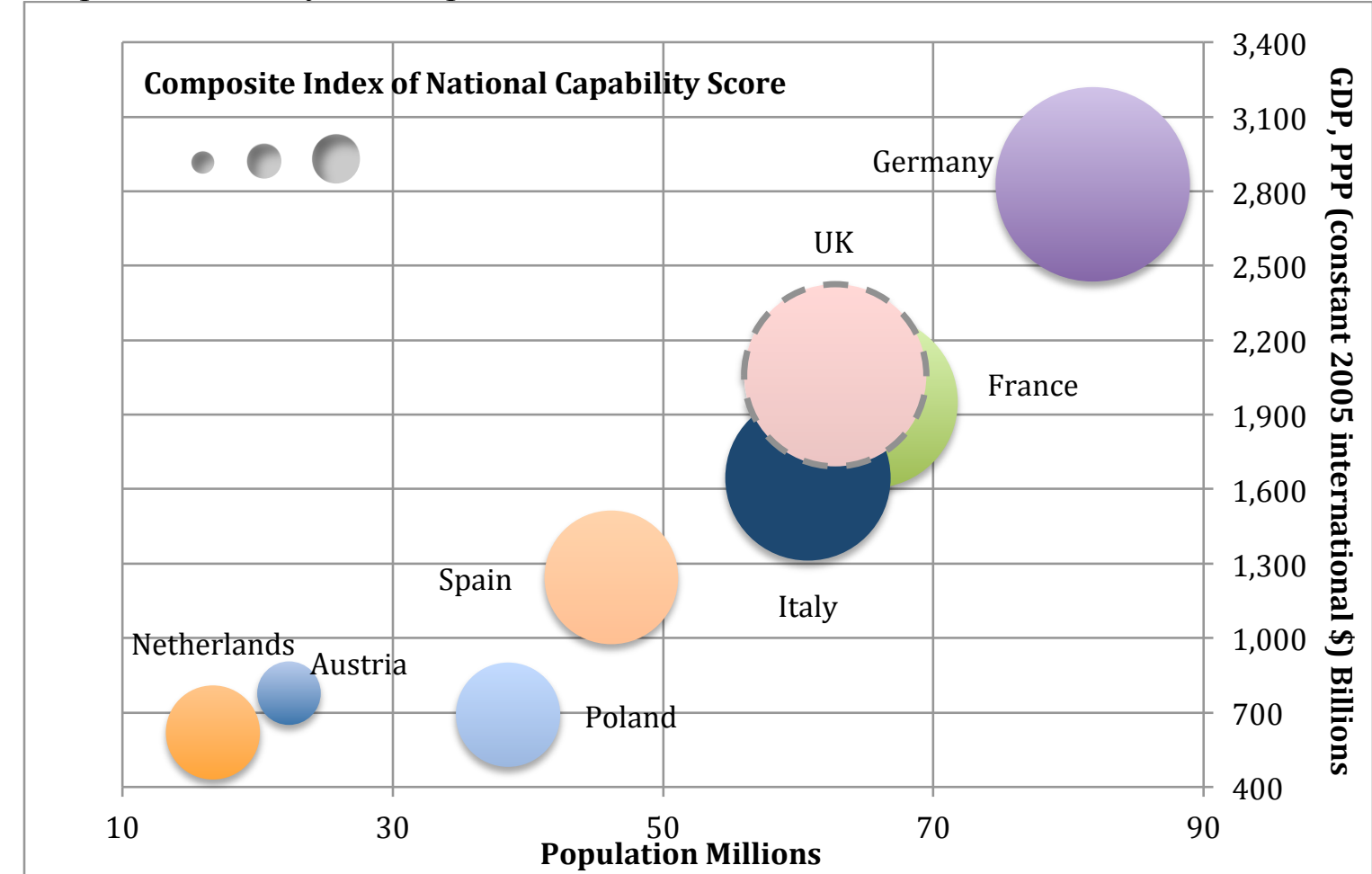

Source: GDP and population data (2011) is from World Development Indicators 2013

Composite Index of National Capabilities Score (2007) (v4.0) (Singer, 1987)

The second step in the analysis is to evaluate the level of satisfaction in the status

quo. Britain's level of satisfaction reflects similar policies and preferences it has with other members of the Union. Consequently, the level of satisfaction in this study will be taken as the satisfaction with the regional status quo, European integration, rather than the satisfaction with the global status quo. The level of satisfaction is going to be measured by the following two Eurobarometer (2013) survey questions:

1. And, for each of them, please tell me if you tend to trust it or tend not to trust it? European Commission Tend to trust 
Graph XI: The percentage of citizens who 'tend to trust' the European Commission

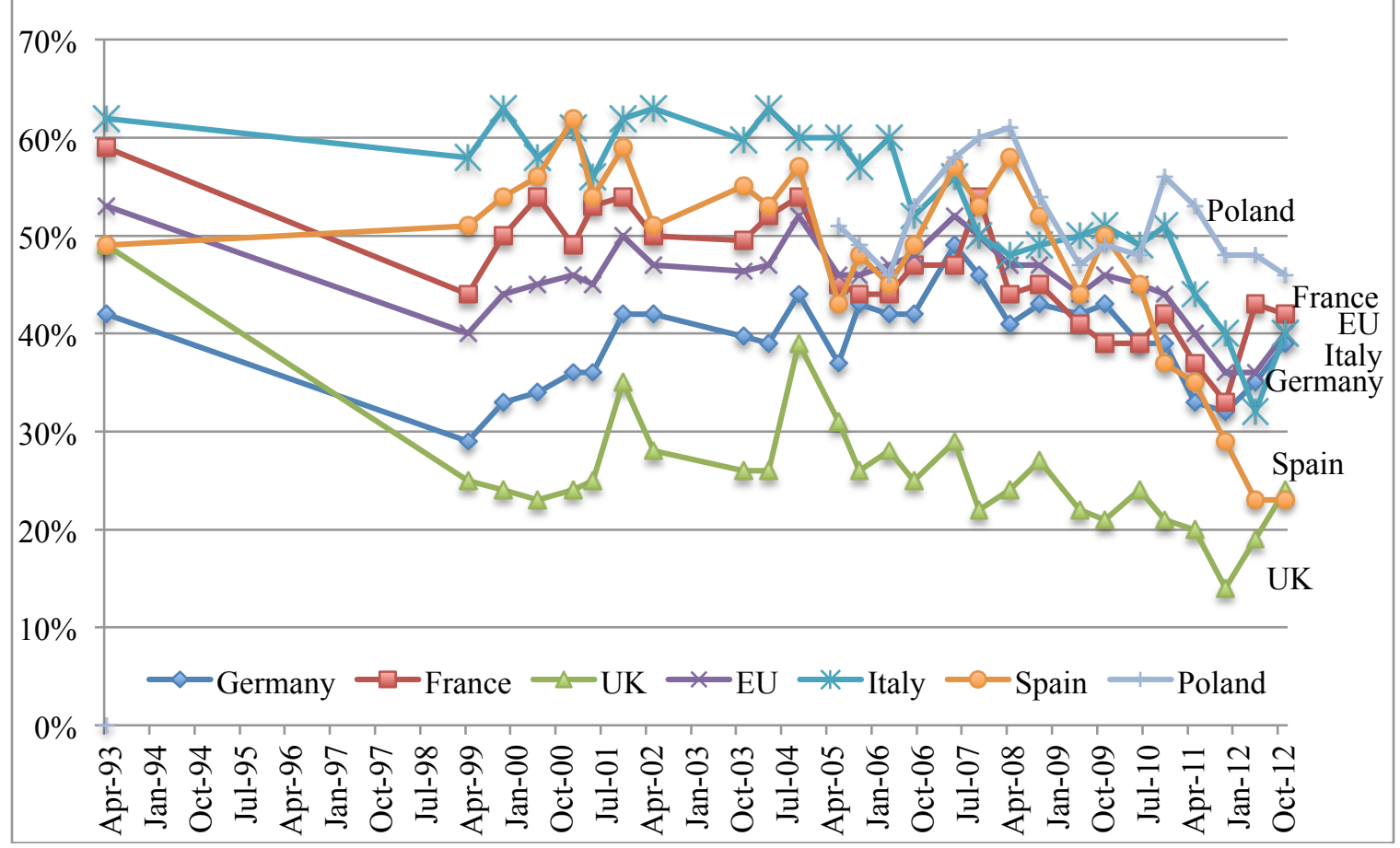

Source: Eurobarometer 2013

2. Generally speaking, do you think that (your country's) membership of the European Community (Common Market) is ...?

A good thing (percentage) 
Graph XII: The percentage of people who thinks their country's EU membership is 'a good thing'

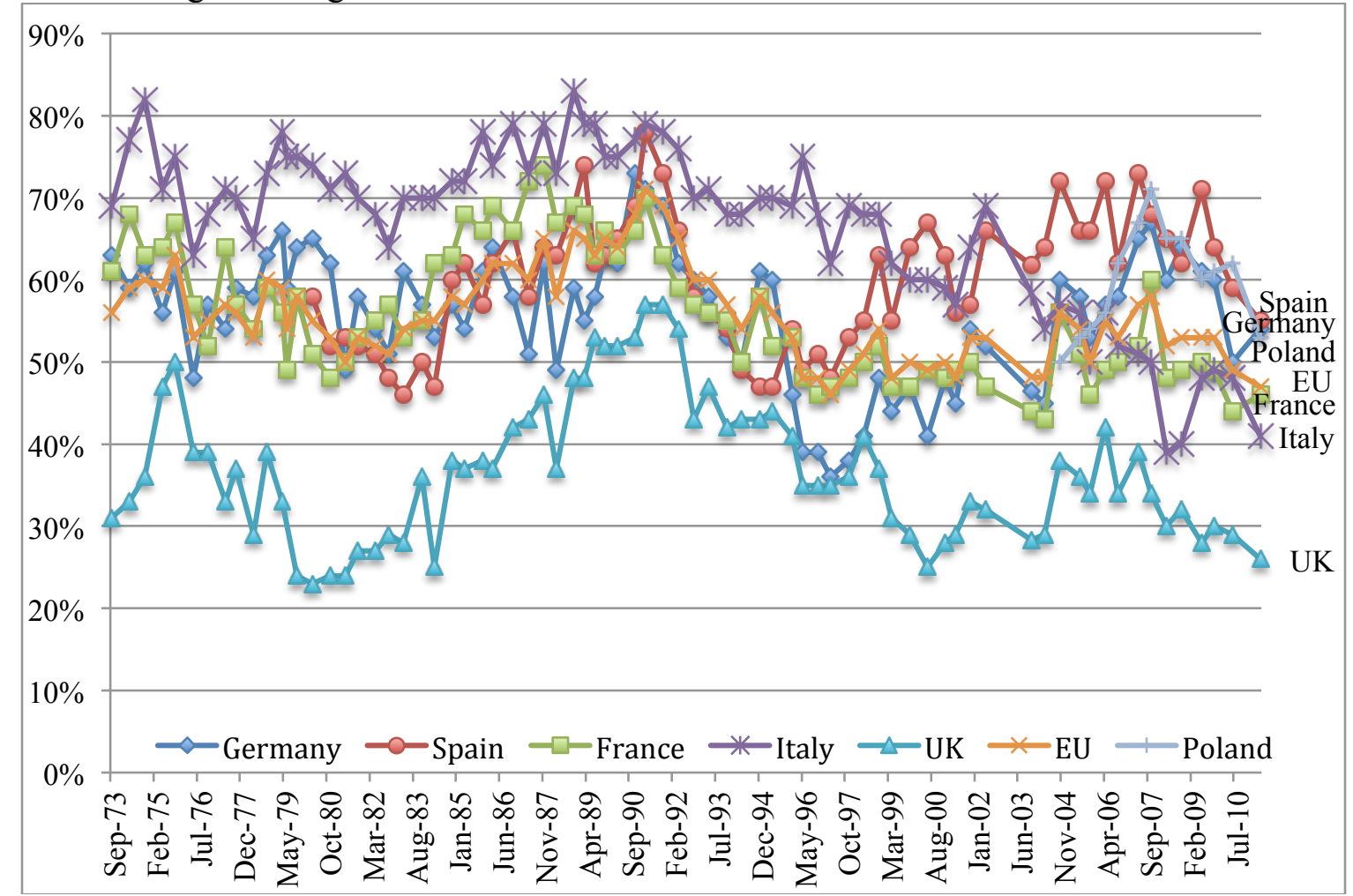

Source: Eurobarometer 2013

The level of satisfaction with the EU is lowest with British citizens. The first question used to measure the level of satisfaction is related to trust. Graph XI depicts the percentage of people who 'tend to trust' the European Commission. For simplicity, only the major power's level of satisfaction is illustrated in the graphs. Compared to the other members, British citizens have the lowest level of trust for the Commission. Similarly, the replies to the second question depict the dissatisfaction of British citizens. Compared to the other nations, the percentage of people who think their country's EU membership is 'a good thing' is the lowest among British people. As a result, both of these survey questions indicate that Britain has the lowest level of satisfaction in the Union compared to the other members. 
By combining the hierarchy and the level of satisfaction information, an assessment of conflict-cooperation can be made. Being one of the great powers of the hierarchy, the UK is not an ordinary country. In terms of GDP and Composite Index of National Capability Score, Britain is the second most powerful nation in the Union. Consequently, the weight of influence of the UK on the European status quo is not going to be same with countries placed at the lower levels of the hierarchy, such as Poland, Greece or Latvia. The more relative power a country has in a hierarchy, the more influential it is in the status quo. As a result, according to Power Transitions, being a powerful nation in the regional hierarchy, the level of Britain's dissatisfaction is going to create conflict on the European integration.

\section{Conflict - Integration Model}

This paper aims to measure the impact of Britain's dissatisfaction on the European integration. To be able to capture Britain's impact empirically on the EU, the following formula, which was proposed by Brian Efird, Jacek Kugler and Gaspare Genna (2003), will be used:

$$
C I=R P-S\left(R P^{3}\right)+H_{C}+H_{D}
$$

$\mathrm{CI}=$ Conflict - integration continuum

$\mathrm{RP}=$ Relative power

$\mathrm{S}=$ Level of satisfaction with the status quo

$\mathrm{H}_{\mathrm{C}}=$ Hierarchy of the challenger

$\mathrm{H}_{\mathrm{D}}=$ Hierarchy of the dominant power

The conflict- cooperation model will be modified in this paper to be able to capture the European regional hierarchy. The original formula was designed to capture 
both military conflicts and cooperation with war and integration at respective extreme ends. However, analyzing the European integration, the probability of military conflict is very low. Therefore, this paper focuses only on the cooperation side of the continuum as it is illustrated in Figure III. Besides differing from the original formulation, this paper will use the two Eurobarometer survey questions related to trust and membership to account for the satisfaction with the regional status quo. As a result, the model is modified to capture the level of conflict even in a high level of integration. The new model is designed to measure the impact of Britain's dissatisfaction on the European integration - towards further integration or just staying at certain level of cooperation as shown in Figure III.

Figure III: Modified conflict- integration continuum

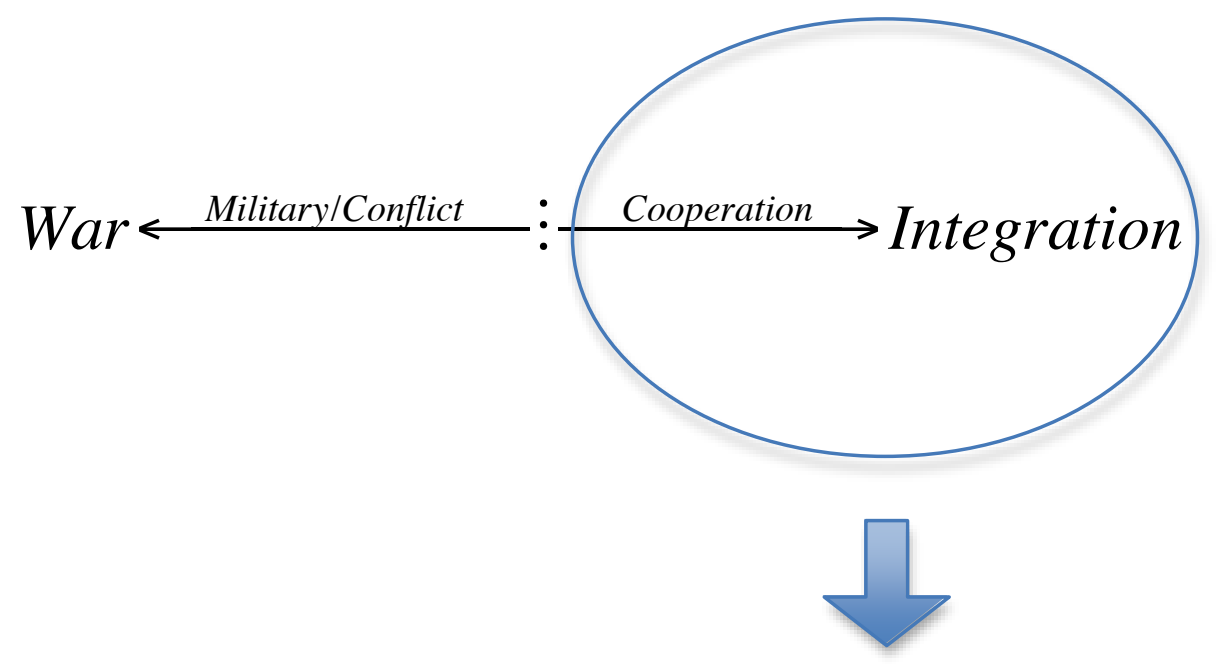

\section{Cooperation $\stackrel{\text { Increasing/Integration }}{\longrightarrow}$ Political / Union}

Conflict- integration continuum represents a measure starting from 0 to 8 . Being in the middle of the measure, 4 represents neutrality as illustrated in Figure IV. From 4 to 8 the level of conflict with integration increases. For Britain, the highest level of conflict, 
8, can indicate reversing EU integration. On the other side, from 4 to 0 the support for integration increases. Since 0 is the highest level of cooperation, this end can denote the highest level of integration: political union (Figure IV).

Figure IV: Conflict - integration continuum

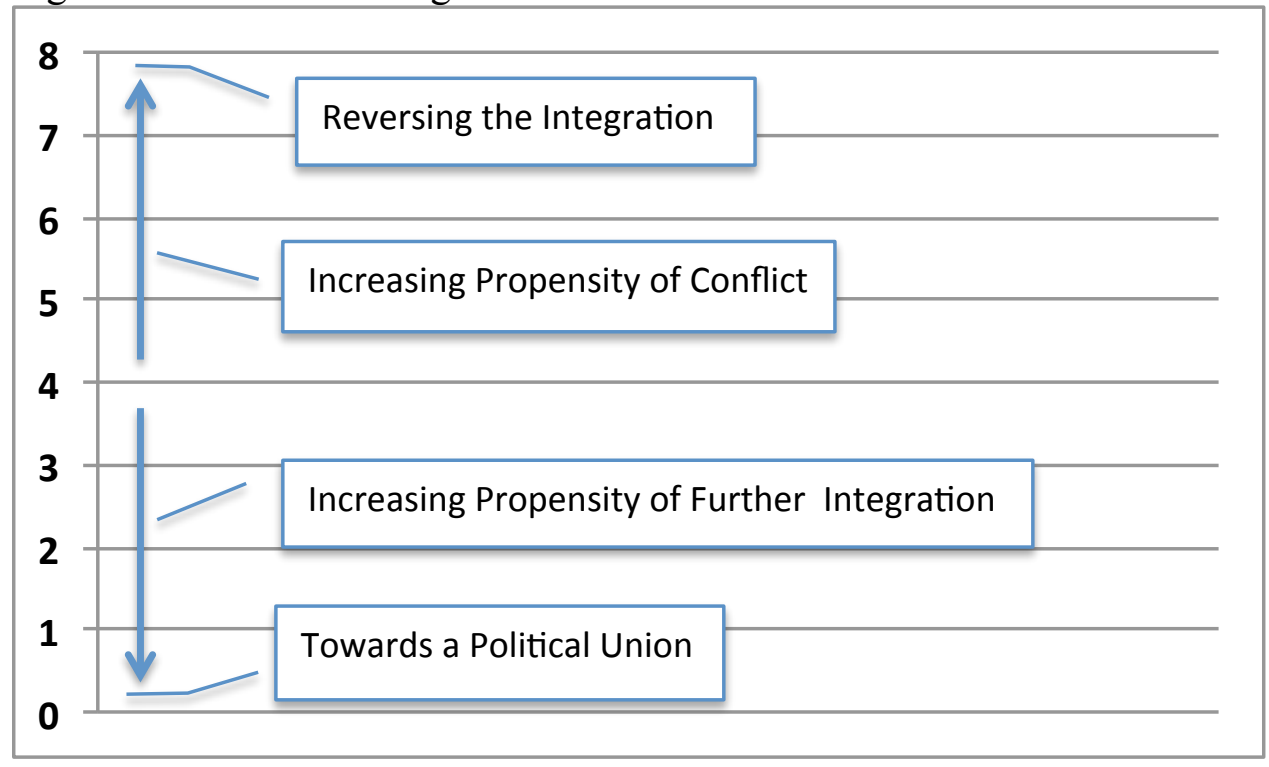

Relative power is the capacity of one nation to influence another either by persuasion or by force. The more relatively powerful a nation is, the more capable it is to impose its preferences on the others in its hierarchy. In this model GDP at purchasing power parity (with $2005 \$$ ) will be used to measure power. Since it is intended to run a simulation with the model until 2050, GDP data is taken from International Futures version 6.69. In trying to determine how influential the UK can be against German leadership, relative power is going to be taken as follows:

$$
R P=\frac{G D P_{U K}}{G D P_{\text {Germany }}}
$$

The closer the level of GDP of the challenger to the dominant power, the less orderliness there is in that hierarchy. Therefore, the higher the level of UK's GDP relative to 
Germany's, the lower the level of orderliness will be in the European hierarchy. This situation is captured by the formula because an increase in RP will be reflected as an increase in the conflict-integration score, meaning a higher probability of conflict. When Germany's GDP level increases more than the UK's GDP, RP will start to get smaller and decrease the probability of conflict on the conflict- integration continuum.

The satisfaction variable represented with ' $S$ ' in the formula defines whether the RP will create conflict or not. As it is mentioned before, two Eurobarometer questions related to 'trust' and 'membership' are going to be used to account for the level of satisfaction with the status quo. The survey question data related to 'trust' and 'membership' are in percentages. To be able to use these data in the conflict- integration formula, it is rescaled between -1 to 1 . As a result, percentages between 50 to 0 are rescaled between 0 to -1 , and percentages between 50 to 100 are rescaled between 0 to -1 . When the level of satisfaction is below $50 \%$, it is going to be transformed into a negative number representing dissatisfaction between 0 and -1 , and due to the negative sign before the ' $\mathrm{S}$ ' variable in the formula, the dissatisfaction level will cause an increase on the continuum representing an increase in the level of conflict. If the level of satisfaction is higher than $50 \%$, rescaling the number will transform it into a positive number between 0 to 1 , and due to the negative sign before the ' $\mathrm{S}$ ' variable in the formula, the model will perceive it as an increasing level of cooperation/ integration.

The data of the question related to 'trust' is adjusted to be able to use in the conflict- integration model. As it can be seen from Graph XI, the data of the question related to trust between 1999 and 1993 is missing. This missing period is interpolated to be able to use in the formula. Furthermore, as it can be seen from Graph XI and Graph 
XII, the data of the first question 'trust' does not go back to 1973 like the data of the second question regarding 'membership'. Therefore, the 'trust' data is extrapolated from 1993 to 1973, which is the date when the UK became a member of the Union.

The trust variable captures the level of satisfaction with the status quo better than the alliance portfolios. In classic Power Transitions analysis, the similarity of alliance portfolios have been used to measure the level of satisfaction with the status quo. The similarity of alliance portfolios is calculated via dyadic relationships. It is inferred that "dyads with similar portfolios are satisfied with each other's view of the international system or dyadic relationship, and those with dissimilar portfolios are regarded as less satisfied with each other" (Efird, Kugler, \& Genna, 2003, p. 297). However, this measurement comes with two fundamental problems in terms of what this paper assesses. First, similarity of alliance portfolios does not directly account for the status quo. Second, dyadic relationship does not capture the behavior or interaction of multiple countries. Encapsulating multiple countries functioning is significant especially when there is a certain level of integration between countries. When countries go into integration, the rules and guidelines of the integration become the status quo. In this situation, to be able to account satisfaction, one should directly focus on integration instead of dyadic alliance similarities. Therefore, directly representing the European integration, trust and membership variables capture the level of satisfaction with the status quo.

The cubed RP term in the formula captures the propensity for conflict in Power Transitions. If the RP term in the interactive part of the equation was linear, each unit increase of RP would cause equal increases on the conflict- integration continuum. If RP was squared, it would not reflect the likelihood of conflict at parity points. Since 
$R P=$ Power $_{\text {Challenger }} /$ Power $_{\text {Dominant }}$, the formula should reflect the probability of conflict once the relative power of the challenger increases in terms of the dominant power. It is anticipated that the likelihood of conflict peaks when the challenger and the dominant power are in parity. For this reason, squaring RP would underemphasize the amount of conflict. However, cubing RP gives the highest propensity for conflict right after the challenger passes the parity point with the defender. Additionally, the cubed RP also reflects the higher probability of cooperation when the asymmetry between the dominant power and the challenger increases (Efird et al., 2003).

$\mathrm{H}_{\mathrm{D}}$ and $\mathrm{H}_{\mathrm{C}}$ reflect the relative power of the dominant power in terms of all the contenders in the region. The calculations of these variables are as follows:

$$
\begin{aligned}
H_{D}= & \frac{\text { Power }_{\mathrm{Re} \text { gional/Dominant }}}{\sum \text { Power }_{\mathrm{Re} \text { gional/Contenders }}} \\
H_{C}= & \frac{\sum \text { Power }_{\mathrm{Re} \text { gional/Contenders }}}{\text { Power }_{\mathrm{Re} \text { gional/Dominant }}}
\end{aligned}
$$

When the power of the dominant country decreases compared to the contenders in the hierarchy, the total of $\mathrm{H}_{\mathrm{C}}$ and $\mathrm{H}_{\mathrm{D}}$ increases to reflect the increasing propensity for conflict. When the powers of the contenders increase compared to the dominant power, $\mathrm{H}_{\mathrm{C}}$ 's increase will be more than $H_{D}$ 's decrease to reflect higher propensity for conflict. The model will first take the regional contenders as UK, France, Italy, and then Spain and Poland will be included as well.

\section{Empirical Results}

The results of the conflict- integration model are depicted in Graph XIII by using two satisfaction data: survey questions related to 'trust' and 'membership'. The lower 
two lines, representing 'trust' and 'membership', are calculated with the data of Germany, UK, France and Italy. In the conflict- integration calculation of the lower two lines, the $\mathrm{H}_{\mathrm{C}}$ and $\mathrm{H}_{\mathrm{D}}$ are formulated as follows:

$$
\begin{aligned}
& H_{D}=\frac{G D P_{\text {Germany }}}{G D P_{U K}+G D P_{\text {France }}+G D P_{\text {Italy }}} \\
& H_{C}=\frac{G D P_{U K}+G D P_{\text {France }}+G D P_{\text {Italy }}}{G D P_{\text {Germany }}}
\end{aligned}
$$

The upper two lines, 'trust+' and 'membership+', that diverges from the bottom two at 1986 are calculated including Spain and Poland in $\mathrm{H}_{\mathrm{C}}$ and $\mathrm{H}_{\mathrm{D}}$. The trends of the lower two and upper two indicate that 'trust' and 'membership' data are consistent with each other.

Graph XIII: UK's conflict- integration scores

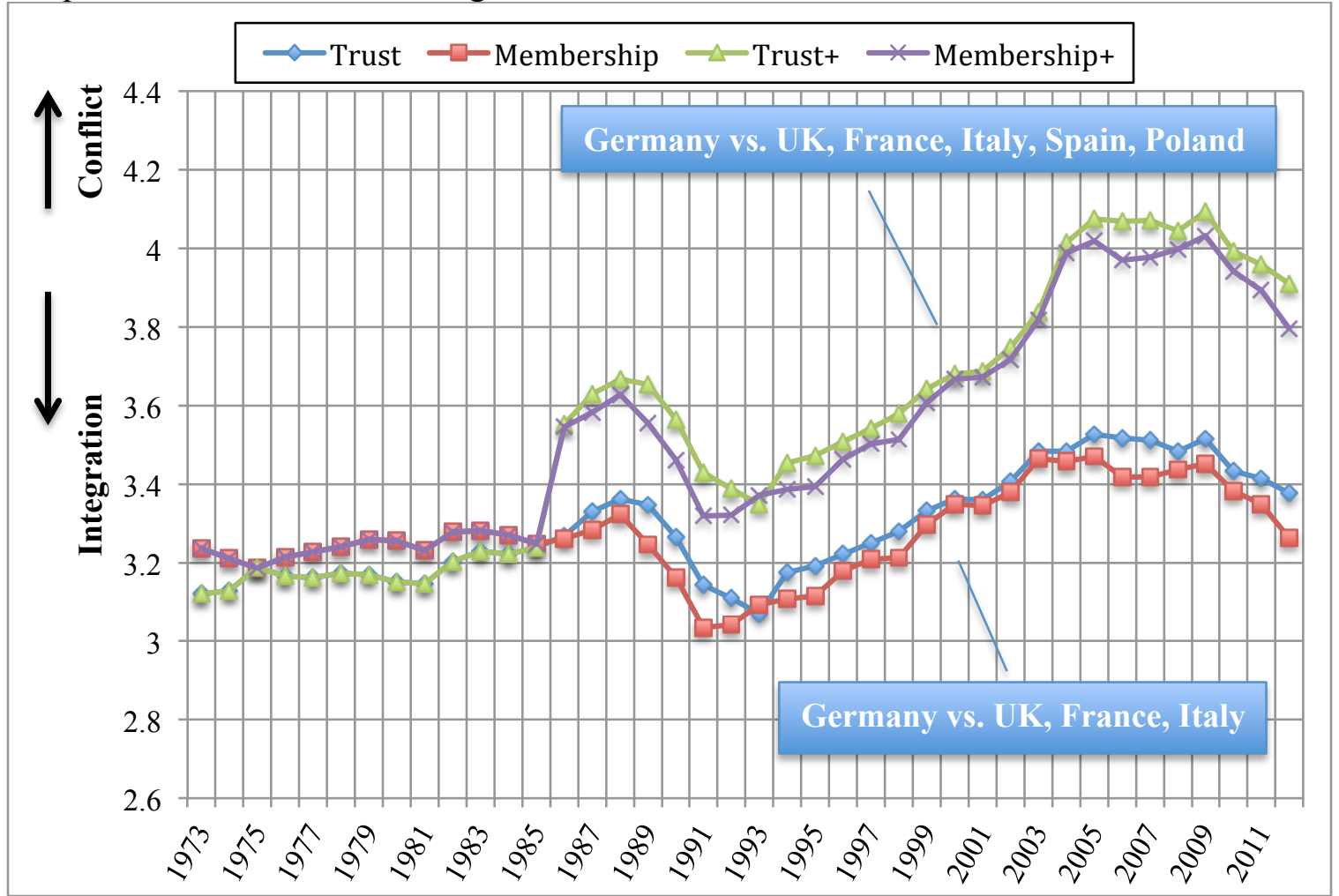


This conflict- integration calculation does not represent a classis dyadic relationship. Mathematically in the hierarchy calculation $\left(\mathrm{H}_{\mathrm{C}}\right.$ and $\left.\mathrm{H}_{\mathrm{D}}\right)$, the variables are taken as Germany versus the UK, France and Italy, depicted in Graph XIII, and in the upper two lines it is Germany versus the UK, France, Italy, Spain and Poland. However, since the satisfaction variables, trust and membership, are measuring Britain's level of satisfaction with the EU, the model accounts for the level of conflict between the UK and the EU. When we say the EU, this can be perceived in several ways: the EU status quo, the EU integration process, or the major representatives of the EU integration process.

The results empirically depict the conflict due to Britain's dissatisfaction. As it can be seen on Graph XIII, according to the data between 1973 and 2012, the probability of conflict related to the UK's relationship with the EU runs between 3 and 4. The graph illustrates that conflict- integration results are not close to 0 , meaning the UK had never supported further integration in its relationship with the EU. One can ask if the relationship between the UK and the EU is conflicting, why the results of the conflictintegration model are not higher than 4 (neutral). Due to the relative power of the dominant power, Germany, further increase of the conflict probability had been prevented. However, as it can be observed from Graph XIII, when Spain and Poland are added to the formula according to their entrance dates (Spain $1986 \&$ Poland 2004), the impact of the dominant nation decreases in the hierarchy and the probability of conflict originated from the UK increases. Therefore, we see a second upper line group with a jump in the level of conflict in 1986 and another one in 2004. Consequently, the focus of the analysis will be the trend of the conflict- integration results instead of the area in the continuum. 
Deepening of integration in the EU creates further dissatisfaction in the UK. As it can be seen from Graph XIII, the probability of conflict increases after 1993 and 1994. According to the data, there are two reasons for this situation. First, RP is increasing, meaning that the power gap between Germany and the UK is decreasing. As Power Transitions explains, the smaller the power-gap between the dominant nation and the challenger, the higher the probability of conflict will be. The second reason is the decreasing level of satisfaction in the UK. Starting from 1991 membership and from 1993 trust variables have been decreasing, which is an indication of rising dissatisfaction. Power Transitions underscores that decreasing satisfaction increases the propensity of conflict especially when the relative power of the challenger is increasing. The decrease in the level of satisfaction starting from 1991-1993 until 2012 (end-year of the data) might be related to the deepening of integration due to the development of the Economic and Monetary Union (EMU) and the attempts to have new constitutional structures - the Amsterdam Summit, Agenda 2000. The level of integration was taken to a higher level with the Maastricht Treaty in 1992 and the integration process continued onwards with the stages of the EMU. Because of not sharing the same European vision with the other members of the Union, joining the EMU and using the euro translates to the British people as losing sovereignty. Hence, the UK opted out from the third stage of the EMU and has not introduced the euro. At the period between 2010 and 2012, the probability of conflict drops a little bit, but this is solely related to the decreasing RP, meaning that the GDP gap between the UK and Germany increased. As a result, the dissatisfaction of British citizens had been increasing the probability of conflict between the UK and the other member countries. 
Using the conflict- integration formulation, it is possible to run simulations to estimate future probability of conflict. Estimated future country GDPs, available from the database of International Futures (IFs), can be used in the conflict-integration calculations. By inserting possible satisfaction levels to the formula for each future year, we can calculate the future probability of conflict between the UK and the EU. If the possible satisfaction values from, -1 to 1 , are inserted to the calculation for each future year, a three dimensional map of conflict can be generated as Graph XIV.

Graph XIV: Forecasting the probability of conflict between the UK and the EU $\mathrm{H}_{\mathrm{D} / \mathrm{C}}=$ Germany vs. UK, France, Italy

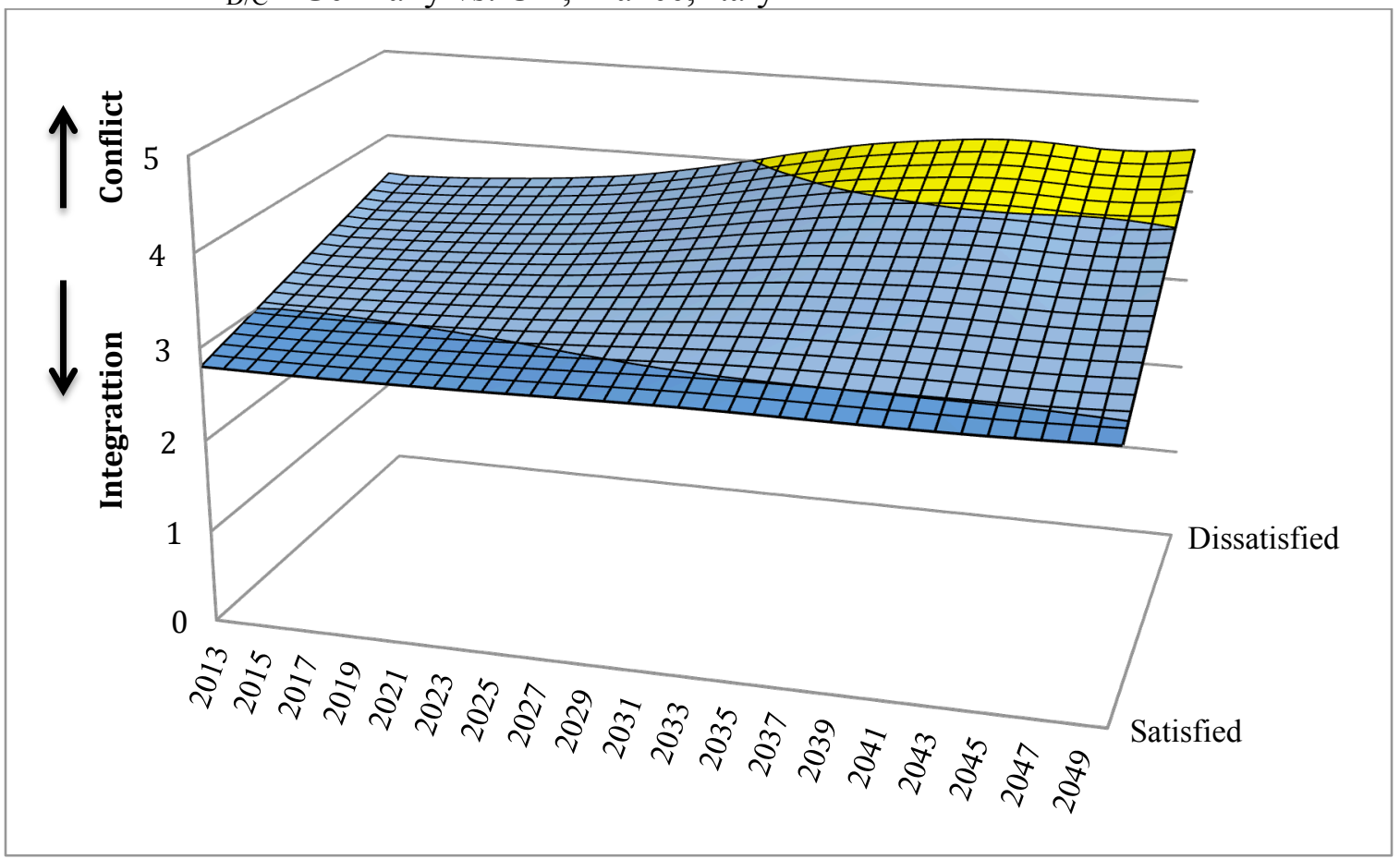

When we run a simulation using the conflict- integration model for the years between 2013 and 2050, a rising probability of conflict can be observed between the UK and the EU. According to Graph XIV, if the level of dissatisfaction increases in the UK, after 2031 the probability of conflict will pass level 5 on the conflict- integration continuum. Above the middle point 4, the increasing likelihood of conflict is depicted 
with light yellow, which is the highest surface area in Graph XIV. The propensity of conflict increases due to the relative power (RP) because according to the data of IFs, the GDP gap between the UK and Germany will decrease, and starting from 2028 they are going to start running in parity. Starting from the year 2028, relative power between the UK and Germany is higher than $0.8(\mathrm{RP}>0.80)$, meaning that the UK is going to reach 80\% of Germany's GDP level. According to Power Transitions, once the challenger acquires $80 \%$ of the dominant power's capabilities, the propensity of conflict increases. The propensity of conflict increases until the challenger procures $20 \%(\mathrm{RP}=1.20)$ more capabilities than the defender, which is not the dominant power anymore.

Being in parity with the dominant nation is a leadership opportunity for the UK. According to the International Futures dataset, around 2058 Britain's GDP level will be equal to Germany's $(\mathrm{RP}=1)$. With the UK's current level of satisfaction, this is a sign of high conflict. On the other hand, if the UK increases its commitment for European integration, this is a valuable opportunity for Britain to shape the regional status quo. If the overtaking between the UK and Germany happens without conflict, the UK can build a strong leadership with the support of Germany and other great powers. Then, it can shape the status quo. For instance, using this leadership opportunity, the UK can initiate the inclusion of services sector in the Common Market. However, to be able to lead the EU, the UK needs to prove its commitment for European integration. Without proving its European ideals, the UK will not be able to have the support from other member states. When Spain and Poland are added to the hierarchy calculation in the formula, the rising propensity of conflict becomes much more visible. As it can be seen from Graph $\mathrm{XV}$, the light yellow area on the surface is now wider, representing higher propensity of 
conflict. After 2038 we even observe an area over 5 on the conflict- integration continuum, which can be identified as a 'high risk' area. Consequently, if the UK's level of dissatisfaction continue to increase, after the year 2038 the likelihood of conflict between the UK and the other EU members is going to be very high. This rising propensity of conflict is a serious threat on the European integration process.

Graph XV: Forecasting the probability of conflict between the UK and the EU $\mathrm{H}_{\mathrm{D} / \mathrm{C}}=$ Germany vs. UK, France, Italy, Spain and Poland

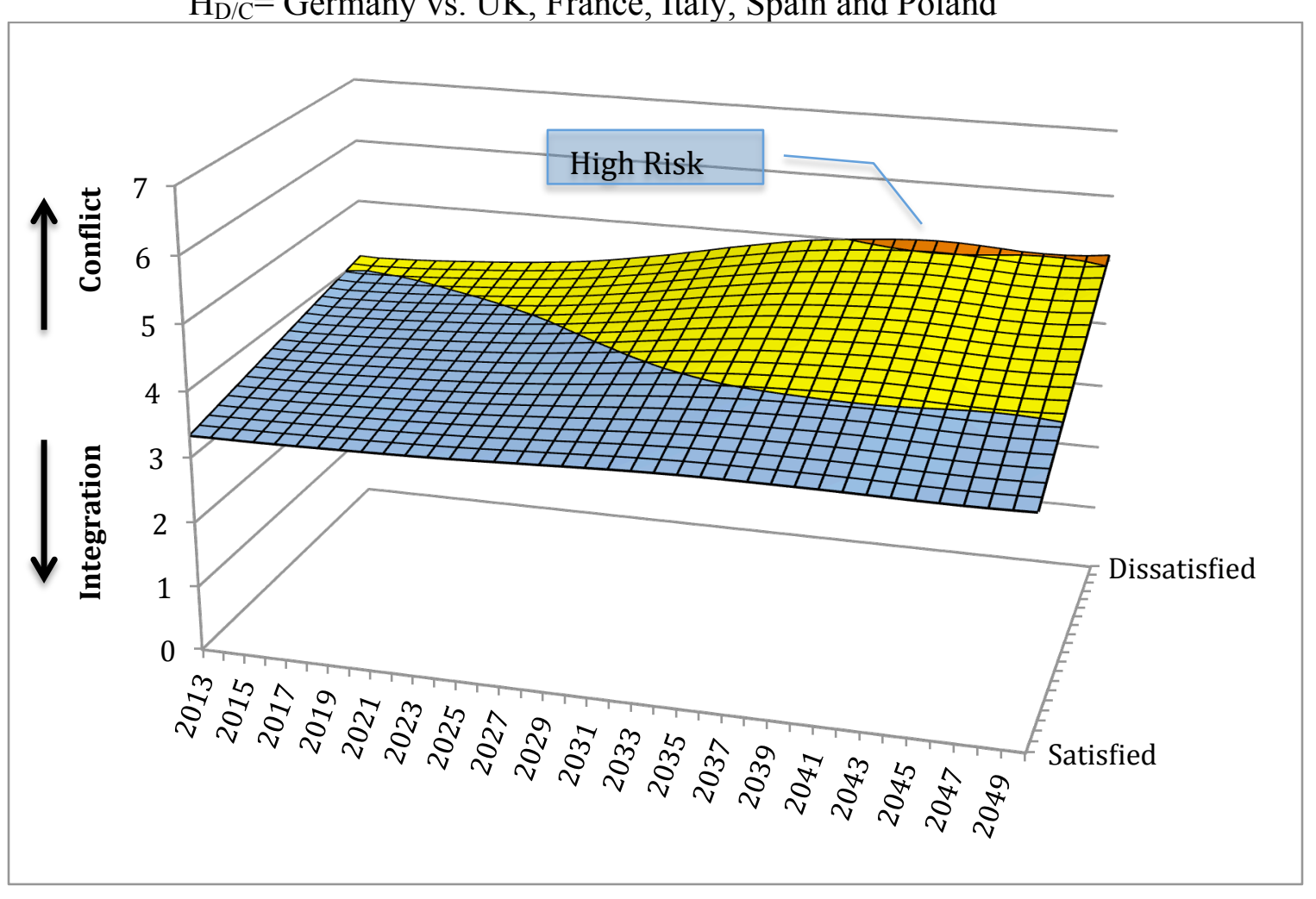

\section{EU's Future Development in the Long Run}

By using Power Transitions perspective and the International Futures database, it is possible for us to forecast the consequences of the UK's possible departure from the EU. If the UK decides to leave the EU in 2018 after a referendum, both the UK and the EU will be affected significantly. The consequences of such a departure are depicted in Graph XVI. The vertical axis depicts the level of GDP, the horizontal axis the level of 
population, and the sizes of the bubbles represent GDP per capita. According to the results, from the standpoint of the UK, it is clear that the country would lose its influence in the international system. Leaving the EU, the UK would end up as a small actor in the international system, depicted in the lower left corner of the Graph XVI. Compared to the EU and the US, Britain would have a much lower place in the global hierarchy. In terms of its level of GDP and population, it would not be possible for the UK to be influential in the international system. On the other hand, the UK's departure would also affect the EU's level of power. As it can be seen from Graph XVI, if the UK leaves the EU in 2018, a downward shift is expected from the Union in terms of GDP and population. In the graph below it can be observed that EU28 (including the new member Croatia) is underneath the US due to its level of GDP. If the UK leaves the Union, EU28 would drop to EU28-UK, which presents the EU without Britain. This fall that we observe in Graph XVI might not change the position of the EU in the global hierarchy; however, this situation would cause a decrease in the relative power of the EU. For instance, the power gap between the US and the EU would be much wider. 
Graph XVI: Forecasting UK's departure from the EU, 1960 - 2100

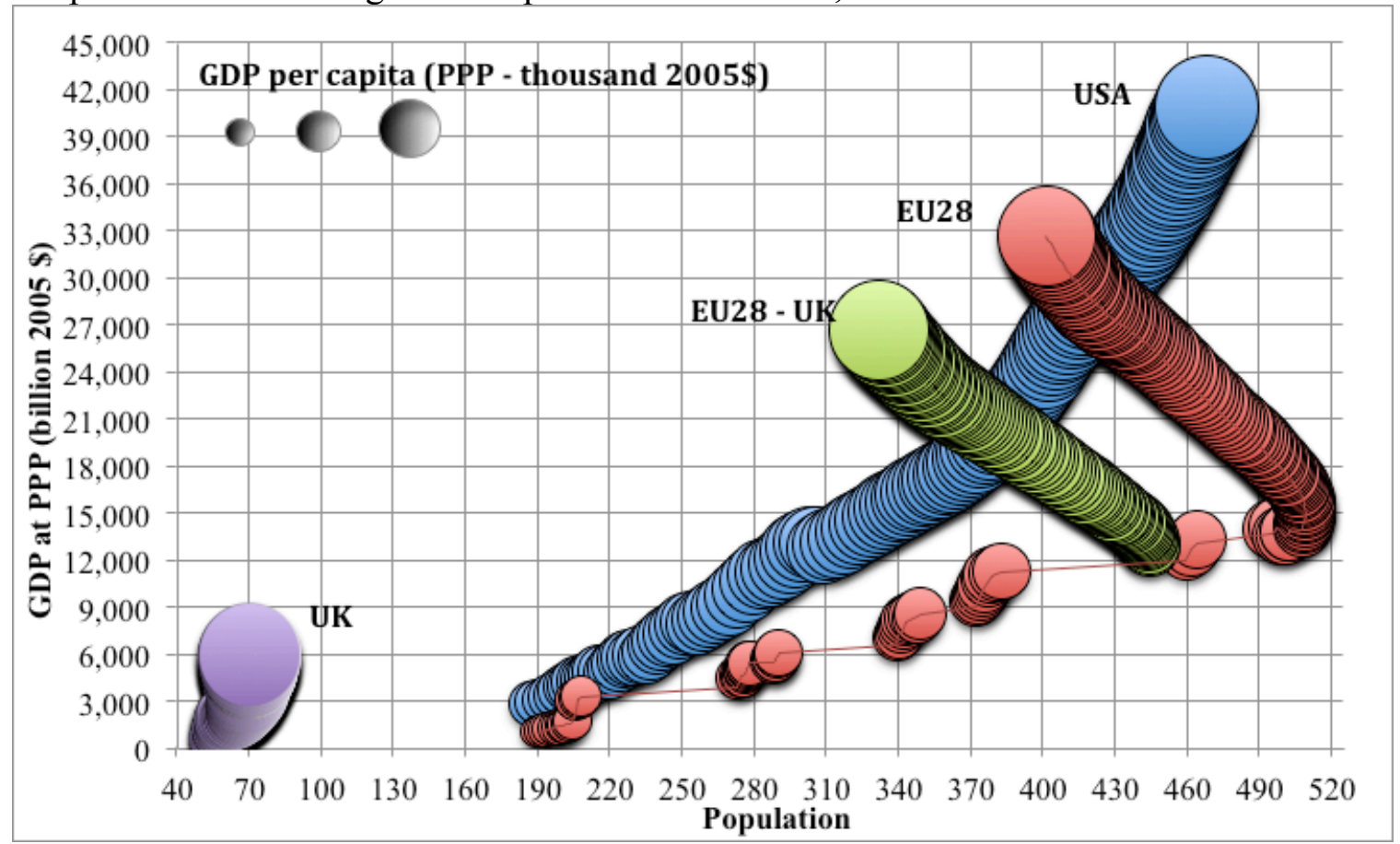

Source: International Futures (IFs)

When the future global actors and their potential power are taken into account, it becomes clear how important it is for the UK and the EU to cooperate. According to the database of International Futures, the US's level of GDP will be passed by China around 2021 and by India around the year 2042. As it is depicted in Graph XVII, indicators show that in the future, China and India are going to surpass today's dominant and great powers in the global hierarchy. As the timeline analysis between 1960 and 2100 in Graph XVII depicts, relative power of the US and the EU will become very small compared to China and India. In such scales of global actors, the UK by itself would only be perceived as an insignificant speck in the international system. As a result, due to the rising new global actors from Asia, deeper levels of integration seems as the only option for the Western countries to survive in the international system. 
Graph XVII: Forecasting EU's global position, 1960 - 2100

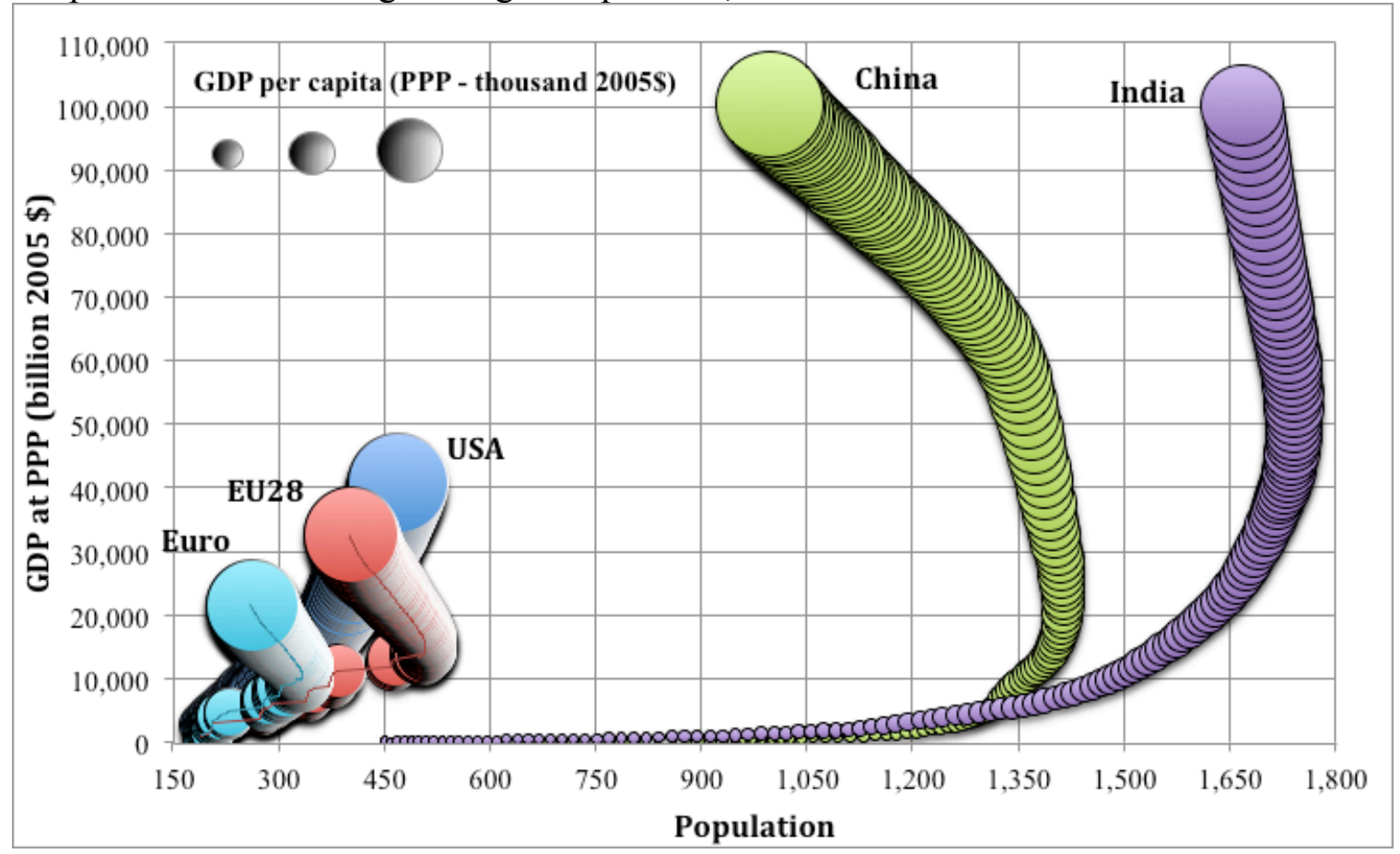

Source: International Futures (IFs) 


\section{Contribution to the Literature \& Further Research}

For the development of the scientific enterprise, it is significant to understand where this study fits in literature and what kind of further research opportunities it brings. The way it defines Britain and how it empirically measures Britain's impact on EU integration makes this study an original one. However, this is not sufficient for us. There is always room for scientific development. For the continuation of this development, we need to understand the place and contribution of this study in Power Transition literature, and realize the limitations of our study.

This study contributes to the scholarly enterprise in several ways. There have been many studies analyzing the relationship between the UK and the EU - defining the UK as "the awkward partner". Lacking of a theoretical framework, in most of the studies regarding this topic, political events are usually presented to the audience in a historical timeline, and the reasons behind the British understanding of European integration are portrayed. However, this paper brings a different approach to the British case in European integration by using Power Transition theory. Instead of analyzing past events between the UK and Britain, this study analyzes empirical data and estimates future outcomes of the relationship.

With this paper, for the first time, the conflict- cooperation formula is applied to an integration model. The calculation is modified to capture the level of conflict in European integration. Using the 'trust' and 'membership' variables to capture the level of satisfaction with the regional status quo is a fairly new concept in Power Transitions literature. The classical Power Transitions analysis focuses on the global level status quo. However, with this paper, it is underscored that to be able to have a better regional level 
conflict encapsulation, one should focus on the regional level status quo. This paper is going to be a strong model indicating that the level of analysis should be consistent with the case that is being analyzed.

This study proves that when the status quo is framed well, it is easier to measure the level of satisfaction. In the case of this study, having European integration as the regional status quo increased the precision of the model, because the concept of European integration is definite with its rules, guidelines (agreements) and institutions. Therefore, the perception of European integration is same in every member country. As a result, a well-defined status quo gives us the ability to better account for the level of satisfaction and increases the accuracy of our measurement for conflict or cooperation.

A micro-level analysis would complete the assessment of this paper. Conflictcooperation analysis under Power Transitions provides the ability to make only macrolevel analysis. For instance, conflict- integration formulation accounts the impact of other countries in the hierarchy only when the weight of the dominant power is being measured. However, the power and the satisfaction levels of France, Italy, Spain and Poland also determine how much conflict can be inflicted on European integration by the UK. Unfortunately, the conflict- integration model does not give us the ability to assess the impact of multiple actors. We cannot really say anything about how the satisfaction levels of the other great powers in the European hierarchy affect the impact of the UK in the regional status quo. Maybe the commitment of other member states to European integration decreases the impact of Britain's dissatisfaction with the status quo.

Testing the coherence of the Union would contribute to this study. We already depicted how Britain is a powerful actor in European hierarchy. Powerful actors will 
make the EU stronger. However, we did not test this argument in terms of the coherence of integration. As it was depicted in Graph XVI, the departure of the UK will cause a downward shift in EU's power trendline. However, we do not really know if or how the departure the UK is going to make the EU weaker. Perhaps coherence will make the Union a more influential actor in the international arena. Economic tests can be applied to understand the relationship between economic utility and level of integration. For example, right now we know that if EU countries do not go through fiscal integration, the economies of countries in the Monetary Union will be especially at risk. As a result, analyzing the benefits of EU coherence would provide a better understanding of the consequences of Britain's departure. 


\section{Conclusion}

The conflict- integration model depicts the impact of Britain's dissatisfaction in terms of conflict. The results of the analysis clearly indicate that current state of relations between the UK and the EU will bring further conflict in the future. The European debt crisis proved that the current state of integration is not sustainable for the Union.

Therefore, conflict created by one of the great powers of the hierarchy is a serious threat for the integration process and the future of the Union.

In a scenario of leaving the EU, the UK would become an insignificant actor in the international system. The empirical results clearly indicate that the UK would lose its economic and political power in the global system if it departs from the EU. As a single country, it is not possible for the UK to keep up with the rising Asian powers: China and India. The deeper the level of integration with the EU, the higher the UK's level of influence will be in the international system.

For the EU, the benefit of having a powerful member is smaller than the costs it brings. If Britain leaves the EU, this would be a serious loss in terms of its level of capability. However, the debt crisis showed that commitment to the integration is more important than the level of GDP to sustain the Union as a global actor. The EU has to avoid any conflict directed to the integration process coming from the members. Otherwise, the Union would lose its coherence and become a weaker actor in the international arena. If Britain is going to stay in the $\mathrm{EU}$, it is significant that it has the European vision for integration. Including Britain into further level of integration without enough commitment for the Union would jeopardize the integration process. If the UK is included in further level of integration without enough commitment, the propensity of 
conflict will be higher. To avoid further conflict, a two-tract formulation can be formulated. Thus Britain and similar countries can take that track, which is a lower level of integration, until they have the vision for further integration.

The future of both the UK and the EU is bound to their ability to compromise and cooperate. Realizing its own capacity and the future power transitions in the global arena should make the UK appreciate its EU membership. On the other hand, the EU should work for methods that will increase the coherence of the member states. Mechanisms that will keep the less commitment members apart will save the speed and the development of the integration process. The highest level of utility in the long run can only come with higher level of cooperation. 


\section{References}

“Amber warning" on attractiveness of UK to financial services companies. (2012, November 9). TheCityUK. Retrieved April 8, 2013, from http://www.thecityuk.com/media/press-releases/amber-warning-on-attractivenessof-uk-to-financial-services-companies/

Balance of Payments, Q3 2012 Dataset. (2012, December 21). Office for National Statistics. Retrieved March 20, 2013, from http://www.ons.gov.uk/ons/rel/bop/balance-of-payments/3rd-quarter-2012/boptime-series-q3-2012.html

Booth, S., \& Howarth, C. (2012, June). Trading Places: Is EU membership still the best option for UK trade? Open Europe, (June).

Britain and Europe: Making the Break. (2012, December 8). The Economist. Retrieved January 26, 2013, from http://www.economist.com/news/briefing/21567914-howbritain-could-fall-out-european-union-and-what-it-would-mean-making-break

Brocklehurst, J., Bundey, J., Crowley, J., Davies, B., Edwards, M., Harrington, S., ... Wood, P. (2012). Correction The Pink Book 2012. (M. Edwards, Ed.) (2012th ed., Vol. 44). Newport: Office for National Statistics.

Bulmer, S. (1992). Britain and European Integration: Sovereignty, Slow Adaptation, and Semi-Detachment. In S. George (Ed.), Britain and the European community: the politics of semi-detachment. Oxford [England]: Clarendon Press.

Cini, M. (2010). Intergovernmentalism. In N. Pérez-Solórzano Borragán \& M. Cini (Eds.), European Union politics (3rd ed.). Oxford; New York: Oxford University Press. 
Deutsch, K. W. (1969). Political community and the North Atlantic area; international organization in the light of historical experience. New York: Greenwood Press.

Efird, B., Kugler, J., \& Genna, G. (2003). From War to Integration: Generalizing Power Transition Theory. International Interactions, 29(4), 293-313. doi:10.1080/714950654

EU summit: UK and Czechs refuse to join fiscal compact. (2012, January 30). BBC News. Retrieved from http://www.bbc.co.uk/news/world-europe-16803157

Eurobarometer Interactive Search System. (n.d.). European Commission: Public Opinion. Retrieved June 28, 2013, from http://ec.europa.eu/public_opinion/cf/index.cfm?lang=en

Foreign Direct Investment: The Netherlands Distortion: (an updated version of Global Briefing Note No 20 dated 31st July 2002). (2004). Global Britain Briefing Note, (32).

Gaskell, S., \& Persson, M. (2010, June). Still out of control? Measuring eleven years of EU regulation. Open Europe.

George, S. (1998). An awkward partner: Britain in the European Community. Oxford; New York: Oxford University Press.

Gowland, D. A., \& Turner, A. (2000). Reluctant Europeans: Britain and European integration, 1945-1998. Harlow, England; New York: Longman.

Greenwood, S. (Ed.). (1996). Britain and European integration since the Second World War. Manchester; New York: Manchester University Press.

Haas, E. B. (1968). The uniting of Europe; political, social, and economic forces, 19501957. Stanford, Calif.: Stanford University Press. 
Haas, E. B. (1971). The study of regional integration: Reflections on the joy and anguish of pretheorizing. In L. N. Lindberg \& S. A. Scheingold (Eds.), Regional integration; theory and research. Cambridge, Mass: Harvard University Press.

Haydon, P. (2013, January 13). EU membership is crucial to Britain's growing car industry. The Guardian. Retrieved June 17, 2013, from http://www.guardian.co.uk/commentisfree/2013/jan/13/eu-membership-britaincar-industry

Hoffman, S. (1966). Obstinate or Obsolete? The Fate of the Nation-State and the Case of Western Europe. Daedalus, 95(3), 862-915.

International transactions in financial services: exports, imports and balance. (2013, March 18). Eurostat. Retrieved March 20, 2013, from http://epp.eurostat.ec.europa.eu/portal/page/portal/statistics/search_database

Intra and Extra-EU trade by Member State and by product group. (2013). Eurostat. Retrieved March 18, 2013, from http://epp.eurostat.ec.europa.eu/portal/page/portal/international_trade/data/databas e

Kugler, J., Tammen, R. L., \& Efird, B. (2004). Integrating Theory and Policy: Global Implications of the War in Iraq. International Studies Review, 6(4), 163-179. doi: $10.2307 / 3699730$

Kugler, J., Yeşilada, B., \& Fisunoğlu, F. A. (in press). Consequences of Reversing the EU Integration. Foreign Policy Analysis.

Lemke, D. (2002). Regions of War and Peace. Cambridge, UK; New York: Cambridge University Press. 
Lindberg, L. N. (1963). The political dynamics of European economic integration. Stanford, Calif.: Stanford University Press.

Menéndez Alarcón, A. V. (2004). The cultural realm of European integration: social representations in France, Spain, and the United Kingdom. Westport, Conn: Praeger Publishers.

Moravcsik, A. (1992). Liberalism and international relations theory. Cambridge, Mass.: Harvard University Press.

Morgenthau, H. J. (2006). Politics Among Nations: the struggle for power and peace (7th ed.). Boston: McGraw-Hill Higher Education.

National accounts - GDP. (2013, January). Eurostat. Retrieved March 22, 2013, from http://epp.eurostat.ec.europa.eu/statistics_explained/index.php/National_accounts _ $\%$ E2\%80\%93_GDP

Nielsen, N. (2012, October 8). UK threatens to veto EU budget. EUobserver.com. Retrieved from http://euobserver.com/economic/117778

Organski, A. F. K. (1968). World Politics. New York: Knopf.

Organski, A. F. K., \& Kugler, J. (1980). The War Ledger. Chicago: University of Chicago Press.

Population, total. (2013). The World Bank: World Development Indicators. Retrieved March 17, 2013, from http://data.worldbank.org/data-catalog/world-developmentindicators

Q\&A: EU fiscal treaty to control eurozone budgets. (2012, January 30). BBC News. Retrieved from http://www.bbc.co.uk/news/world-europe-16057252 Rosamond, B. (2000). Theories of European integration. New York: St. Martin's Press. 
Rowley, E. (2012, May 15). First trade surplus in cars since 1976. The Telegraph. Retrieved June 17, 2013, from http://www.telegraph.co.uk/finance/economics/9267231/First-trade-surplus-incars-since-1976.html

Singer, D. J. (1987). Reconstructing the Correlates of War Dataset on Material Capabilities of States, 1816-1985. International Interactions, (14), 115-32.

Strøby-Jensen, C. (2010). Neofunctionalism. In M. Cini \& N. Pérez-Solórzano Borragán (Eds.), European Union politics (3rd ed.). Oxford; New York: Oxford University Press.

Tammen, R. L., Lemke, D., Alsharabati, C., Efird, B., Kugler, J., Stam, A. C., ... Organski, A. F. K. (2000). Power Transitions: strategies for the 21 st century. New York: Chatham House Publishers.

Tariff Download Facility: WTO tariff data base. (2013). World Trade Organization. Retrieved April 9, 2013, from http://tariffdata.wto.org/ReportersAndProducts.aspx

The International Futures (IFs) modeling system, version 6.69. (n.d.). International Futures. Retrieved July 1, 2013, from http://www.ifs.du.edu/ifs/index.aspx The Rotterdam-Antwerp Effect \& the Netherlands Distortion. (2011). Global Britain Briefing Note, (64).

Trade Profiles: European Union (27). (2012, September). World Trade Organization. Retrieved March 26, 2013, from http://stat.wto.org/CountryProfile/WSDBCountryPFView.aspx?Language=E\&Co untry=E27 
Watts, D., \& Pilkington, C. (2005). Britain in the European Union today. Manchester: Manchester University Press.

Wheeler, B., \& Peter, L. (2013, May 14). UK and the EU: Better off out or in? BBC News. Retrieved June 17, 2013, from http://www.bbc.co.uk/news/uk-politics-20448450

WTO Secretariat. (2011). Trade Policy Review: European Union (No. WT/TPR/S/248). World Trade Organization. Retrieved from http://www.wto.org/english/tratop_e/tpr_e/tp348_e.htm

Yeşilada, B. A., \& Wood, D. M. (2010). The emerging European Union (5th ed.). Boston: Longman.

Yeşilada, B., Efird, B., \& Noordijk, P. (2006). Competition among Giants: A Look at How Future Enlargement of the European Union Could Affect Global Power Transition. International Studies Review, 8(4), 607-622. 